\title{
OPEN Recovery of phosphorus as soluble phosphates from aqueous solutions using chitosan hydrogel sorbents
}

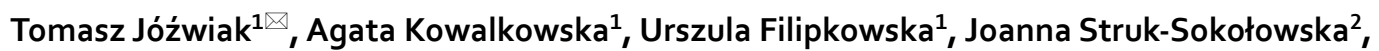
Ludmila Bolozan ${ }^{3}$, Luminita Gache ${ }^{3}$ \& Marius Ilie $^{3}$

This manuscript presents new method of phosphorus recovery from aqueous solutions in a convenient form of readily-soluble phosphates using chitosan hydrogels. Non-modified chitosan hydrogel granules (CHs) and chitosan hydrogel granules crosslinked with epichlorohydrin (CHs-ECH) served as orthophosphate ion carriers. The developed method was based on cyclic sorption/desorption of orthophosphates, with desorption performed in each cycle to the same solution (the concentrate). The concentrations of orthophosphates obtained in the concentrates depended on, i.a., sorbent type, sorption $\mathrm{pH}$, source solution concentration, and desorption $\mathrm{pH}$. Phosphorus concentrations in the concentrates were even 30 times higher than these in the source solutions. The maximum concentrate concentrations reached $332.0 \mathrm{mg} \mathrm{P}-\mathrm{PO}_{4} / \mathrm{L}$ for $\mathrm{CHs}$ and $971.6 \mathrm{mg} \mathrm{P}-\mathrm{PO}_{4} / \mathrm{L}$ for $\mathrm{CHs}-\mathrm{ECH}$. The experimental series with $\mathrm{CHs}-\mathrm{ECH}$ were characterized by higher concentrations of the obtained concentrate, however the concentrates were also more contaminated with $\mathrm{Cl}^{-}$and $\mathrm{Na}^{+}$ions compared to series with $\mathrm{CHs}$. The high content of chlorine and sodium ions in the concentrates was also favored by the low $\mathrm{pH}$ of sorption $(\mathrm{pH}<4)$ and very high $\mathrm{pH}$ of desorption $(\mathrm{pH}>12)$ in the cycles. After concentrate evaporation, phosphorus content in the sediment ranged from 17.81 to $19.83 \%$ for $\mathrm{CHs}$ and from 16.04 to $17.74 \%$ for $\mathrm{CHs}-\mathrm{ECH}$.

Phosphorus is an element of vast economic importance. It is not only essential for each living organism's vital functions but also an integral and irreplaceable component of fertilizers and feedstuffs, and also an important constituent of detergents. Sources of phosphorus exploitation for the global economy's needs include its non-renewable, natural deposits in the form of apatites and phosphorites ${ }^{1}$. Continuous growth of the global population entails, among other things, the increased production of foods and cleansing agents. The growing industry's demand for phosphorus compounds accelerates the exploitation of its depleting deposits. With the current phosphorus deposits exploitation rate, they are estimated that economically feasible phosphate rock will be exhausted within 100-400 years ${ }^{2,3}$. The deficit of this raw material will firstly affect European Union Member States whose natural phosphorus resources are scarce or of no economic importance ${ }^{4}$. Therefore, searching alternative phosphorus sources seems to be a priority, emphasizing its recovery and recycling. Today, the treatment of high-phosphorus wastewater appears to offer greater potential for the recovery of this nutrient ${ }^{5-8}$.

Several methods for phosphorus recovery directly from wastewater have been developed so far ${ }^{9,10}$. The simplest of these include the precipitation methods, and the most often used precipitating agents are calcium compounds ${ }^{11}$. The sludge formed upon precipitation is rich in calcium phosphates to be used as a raw material for the production of mineral fertilizers ${ }^{12}$, which inscribes into the phosphorus recycling strategy. However, this method's drawbacks include the necessity of using a precipitating agent, wastewater salinity, and a relatively low process efficiency.

The nanofiltration method is also a well-known mean to recover phosphorus from wastewater. It does not require strong chemicals and can be used even for wastewater containing low concentrations of phosphorus ${ }^{13}$. This method also requires the presence of calcium ions in the wastewater, which must be introduced to the system, e.g., in the form of calcium hydroxide. The wastewater is pumped under high pressure through a semipermeable polyamide membrane, which traps calcium phosphate microcrystals. The crystals accumulated on

\footnotetext{
${ }^{1}$ Department of Environmental Engineering, University of Warmia and Mazury in Olsztyn, Warszawska St. 117a, 10-957 Olsztyn, Poland. ${ }^{2}$ Department of Environmental Engineering Technology, Bialystok University of Technology, Wiejska St. 45E, 15-351 Bialystok, Poland. ${ }^{3}$ Faculty of Chemical Engineering and Environmental Protection, Gheorghe Asachi Technical University of laşi, Bulevardul Profesor Dimitrie Mangeron 67, 700050 Iaşi,

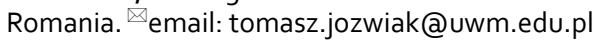


the membrane are then dissolved in the acid solution to obtain a concentrated solution of orthophosphates. The disadvantages of this method include very high investment and operating costs.

Phosphorus can also be recovered from wastewater via the chemical precipitation of magnesium-ammonium phosphate hexahydrate, i.e., struvite ${ }^{14}$. Struvite can be directly used in agriculture as a substitute for phosphorusbased mineral fertilizers ${ }^{15}$. However, the possibilities of phosphorus recovery in the form of struvite are often limited due to specific technical requirements and the difficulty of controlling it. There is also the possibility of biological struvite precipitation using dedicated bacteria, like e.g., Myxococcus xanthus ${ }^{16}$, which allow producing its crystals. In turn, the use of Brevibacterium antiquum results in the formation of magnesium phosphate crystals ${ }^{17}$. Currently, this process is effective only under strictly controlled laboratory conditions.

Newer methods for phosphorus recovery from wastewater include these based on the crystallization of hydroxyapatite under alkaline conditions (DHV Crystalactor process, KURITA). Patented technologies, however, are expensive, require complicated installation, and strictly defined process parameters ${ }^{18-20}$.

The literature provides information on attempts to recover phosphorus from aqueous solutions using sorbents $^{21,22}$. Many research works with "phosphorus recovery" in their title actually focus only on phosphorus sorption and possibly sorbent regeneration, omitting analyses of the actual nutrient recovery ${ }^{23-26}$. In published works, which describe the actual process of phosphorus recovery from aqueous solutions, sorbents were used as carriers for orthophosphate ions, which were transported from the source solution to the target (desorption) solution during sorption/desorption. After desorption, the phosphate ions were precipitated with calcium compounds, e.g., $\mathrm{CaCl}_{2}$ or $\mathrm{Ca}(\mathrm{OH})_{2}$, for their easier separation from the solution. Phosphorus recovered in this way was usually in the form of a water-insoluble sediment containing calcium phosphate- $\mathrm{Ca}_{3}\left(\mathrm{PO}_{4}\right)_{2}$. The sorbent could be regenerated after each desorption and reused ${ }^{27,28}$. The most frequently tested sorbents for phosphorus recovery from aqueous solutions include mineral materials such as metal oxides and hydroxides ${ }^{21,22,29}$ as well as "Layered double hydroxides"-ion exchangers ${ }^{30,31}$. A major drawback of the sorption-based phosphorus recovery methods is the relatively low sorption efficiency of the tested materials, which translates into a low process efficiency. A bigger problem, however, is usually posed by the insoluble form of the recovered phosphorus (phosphate of a divalent or trivalent metal). Reuse of phosphorus contained in calcium phosphate requires its conversion into a soluble form, e.g., by its reaction with hydrochloric acid ${ }^{32}$. This, however, makes the phosphorus recycling process considerably more complicated.

This work presents the feasibility of efficient phosphorus recovery from aqueous solutions in the form of convenient and readily-soluble phosphate salts.

Concept of the novel method for phosphorus recovery from aqueous solutions. The presented method focuses on recovering phosphorus in the form of orthophosphate ions from the source solution, due to its dominance in municipal sewage. The process is based on cyclic sorption/desorption of orthophosphates, following the principle of "sorption in a large volume and desorption in a small volume of wastewater". In each cycle, the desorption is performed into the same solution, leading to the production of a "concentrate". Its concentration increases with each successive cycle until the maximum value. All sorption/desorption cycles are carried out with one and the same sorbent batch. The sorbent is not regenerated between cycles. The obtained "concentrate" can be evaporated, producing sediment with a high phosphorus content (Fig. 1). Since no phosphorus precipitants are needed in this process, the recovered phosphorus has a convenient, water-soluble form of monovalent light metal phosphates.

In the discussed process, hydrogel chitosan granules are used as carriers of orthophosphate ions. Chitosan is a polysaccharide, a deacetylated form of chitin. On an industrial scale, it is obtained from the exoskeletons of sea crustaceans. The possibility of extracting chitosan from the waste products of the seafood processing industry makes it a widely available and relatively cheap material. A characteristic feature of chitosan is its basic character caused by the presence of $-\mathrm{NH}_{2}$ groups in its structure. Chitosan based sorbents already proved their good sorption properties in relation to heavy metals $s^{33-37}$ and dyes ${ }^{38}$. In this study, the choice of chitosan as the base material for sorbent production was driven by the proven high affinity of orthophosphate ions to its amine functional groups. The sorption capacity of a properly prepared chitosan sorbent may even exceed $400 \mathrm{mg} \mathrm{PO}_{4}{ }^{3-} / \mathrm{g}$. The hydrogel form of chitosan improves the penetration of orthophosphate ions into the sorption centers located inside the sorbent and also facilitates quick separation of the sorbent from the solution. The crosslinked form of a hydrogel (with epichlorohydrin) used in some research ensured its stability at $\mathrm{pH} 3$, which is recommended during orthophosphate sorption ${ }^{39}$. Since the binding of orthophosphate ions onto chitosan proceeds via the electrostatic interaction between the sorbate and the sorbent functional groups, the process can theoretically be easily controlled by $\mathrm{pH}$ correction.

The most important results, which are also indicators of the method's efficiency, are the maximum concentration of phosphorus in the concentrate as well as its percentage content in the dry residue. The efficiency of sorption and desorption in individual cycles is essential as well. Presumably, the course of phosphorus recovery from aqueous solutions depends mainly on the composition of source solutions and on the conditions of the sorption and desorption processes.

This study investigated the impact of such parameters as: concentration of orthophosphates in source solutions, $\mathrm{pH}$ of sorption and desorption, as well as sorbent type on the sorption/desorption efficiency in subsequent cycles, the maximum concentration of the phosphate "concentrate" obtained, and phosphorus content in the dry residue left after concentrate evaporation. It was conducted with chitosan hydrogel granules crosslinked with epichlorohydrin [CHs-ECH] and unmodified chitosan hydrogel granules [CHs] used as carriers of orthophosphate ions. 


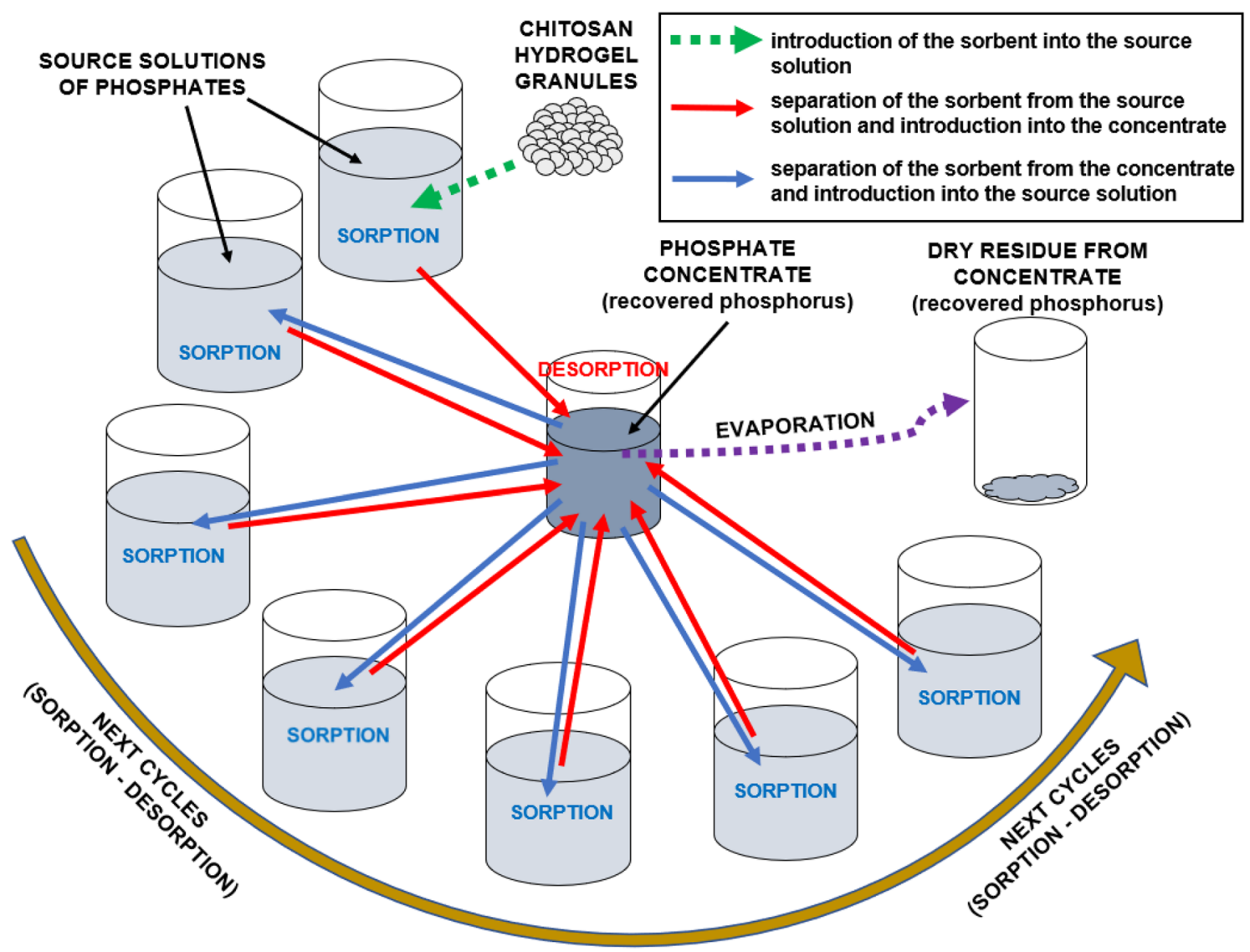

Figure 1. General scheme of the presented method for phosphorus recovery from aqueous solutions in the form of a concentrate and a dry residue from the concentrate.

\section{Materials}

Chitosan-raw material for sorbent production. Chitosan used in the study was in the form of flakes (2-3 mm) (Heppe Medical Chitosan GmbH, Halle, Germany). It was produced from chitin derived from shrimp exoskeletons and characterized by a medium deacetylation degree of $\mathrm{DD}=85.0 \%(\mathrm{DD}=82.6-87.5 \%)$ and viscosity of $500 \mathrm{mPa}\left(1 \%\right.$ wt. in $1 \%$ acetic acid, temp. $\left.25^{\circ} \mathrm{C}\right)$. Its molecular weight ranged from 50 to $190 \mathrm{kDa}$. The total content of heavy metals $(\mathrm{Pb}, \mathrm{Hg}, \mathrm{Cd})$ in the polymer did not exceed $25 \mathrm{ppm}$.

Chemical reagents. The following reagents were used in the study:

- epichlorohydrin (99\%) (ACROS ORGANICS, Poland)-for crosslinking chitosan gel

- hydrochloric acid (37\%) (POCH S.A., Poland)-for $\mathrm{pH}$ correction in aqueous solutions

- sodium hydroxide (> 98\%) (POCH S.A., Poland) - for hydrogel gelling and $\mathrm{pH}$ correction in aqueous solutions

- acetic acid (>99\%) (POCH S.A., Poland)-for dissolving chitosan flakes

- sodium dihydrogen phosphate 1 monohydrate $\left(\mathrm{NaH}_{2} \mathrm{PO}_{4} \times 1 \mathrm{H}_{2} \mathrm{O}\right),(>99 \%)$ (POCH S.A., Poland)-for preparing stock and source solutions.

\section{Methods}

Preparation of non-crosslinked chitosan hydrogel granules (CHs). $25 \mathrm{~g}$ d.m. of chitosan flakes, $925 \mathrm{~g}$ of water, and $50 \mathrm{~g}$ of acetic acid were added into a beaker (vol. $2000 \mathrm{~mL}$ ) and stirred with a spatula until chitosan dissolved completely. The resulting solution with a chitosan concentration of $2.5 \%$ was left for $12 \mathrm{~h}$ to deaerate. Next, it was instilled, using a $0.8 \times 40$ injection needle, to $2 \mathrm{M} \mathrm{NaOH}$ to form hydrogel granules (2.0-2.2 $\mathrm{mm}$ in diameter). Once formed, the hydrogel granules were kept in $2 \mathrm{M} \mathrm{NaOH}$ for $24 \mathrm{~h}$, and afterward rinsed with deionized water on a laboratory screen until neutral $\mathrm{pH}$ of the filtrate. The ready sorbent in the form of chitosan hydrogel granules $(\mathrm{CHs})$ was stored in deionized water having a temperature of $4{ }^{\circ} \mathrm{C}$. The dry mass content in $\mathrm{CHs}$ was $5.4 \%$.

Preparation of chitosan hydrogel granules crosslinked with epichlorohydrin ( $\mathrm{CHs}-\mathrm{ECH})$. The non-modified chitosan hydrogel granules (CHs) were weighed $(10 \mathrm{~g} \mathrm{~d} . \mathrm{m}$.) into a conical flask $(300 \mathrm{~mL})$. Then, an epichlorohydrin (ECH) solution (100 mL, concentration of $3.2 \mathrm{~g} / \mathrm{L}, \mathrm{pH} 11)$ was added to the flask. The sorbent 
was prepared with a minimal dose of epichlorohydrin $\left(0.032 \mathrm{~g} \mathrm{ECH} / \mathrm{g}_{\mathrm{CHs}}\right)$ ensuring complete stability of the chitosan hydrogel in a wide range of $\mathrm{pH}$ values, i.e., $\mathrm{pH} 1-12^{40}$. The flask was protected with a parafilm and placed for $24 \mathrm{~h}$ in a water bath with a shaker (Water bath shaker type 357, Elpin-Plus, Poland; 150 r.p.m., oscillation amplitude $20 \mathrm{~mm}, 60^{\circ} \mathrm{C}$ ). Afterward, the crosslinked chitosan was sifted on a laboratory screen and rinsed with deionized water until neutral $\mathrm{pH}$ of the filtrate. The resulting hydrogel sorbent crosslinked with epichlorohydrin $(\mathrm{CHs}-\mathrm{ECH})$ was stored in deionized water (temp. $4^{\circ} \mathrm{C}$ ). The dry mass content in $\mathrm{CHs}-\mathrm{ECH}$ was $4.2 \%$.

FTIR analysis of the hydrogel sorbents: $\mathrm{CHs}$ and $\mathrm{CHs}-\mathrm{ECH}$, indicating the presence of $-\mathrm{NH}_{2}$ groups (crucial for phosphorus binding), is presented in Supplement 1.

Analysis of $\mathrm{pH}$ effect on orthophosphate sorption efficiency. The hydrogel sorbent $(0.1 \mathrm{~g}$ d.m. $)$ was weighed into a series of conical flasks $(250 \mathrm{~mL})$, to which solutions of sodium dihydrogen phosphate $\left(\mathrm{NaH}_{2} \mathrm{PO}_{4}\right)$ were added $\left(100 \mathrm{~mL}, 10 \mathrm{mg} \mathrm{P}-\mathrm{PO}_{4} / \mathrm{L}, \mathrm{pH} 2-12\right)$. Next, the flasks were placed on a multi-station shaker (Basic Shaker SK-71, JEIO TECH, Korea), and shaken at 150 r.p.m. and oscillation amplitude of $32 \mathrm{~mm}$. After $2 \mathrm{~h}$, samples $(10 \mathrm{~mL})$ were collected from the solution to determine the concentration of $\mathrm{P}_{-} \mathrm{PO}_{4}$ left in the solutions. Solutions' pH was measured after sorption as well. Experiments were performed in triplicate.

Analysis of orthophosphate sorption kinetics. The chitosan sorbent $(2.0 \mathrm{~g} \mathrm{d.m}$.) was weighed into a series of flasks $(2500 \mathrm{~mL})$. Then, $\mathrm{NaH}_{2} \mathrm{PO}_{4}$ solutions $\left(2000 \mathrm{~mL}, 10 / 100 \mathrm{mg} \mathrm{P}-\mathrm{PO}_{4} / \mathrm{L}\right)$ with an optimal sorption $\mathrm{pH}$ (established in point 3.3) were poured into the flasks. The flasks were placed on a magnetic stirrer (150 r.p.m.) (Multi-Channel Stirrer MS-53 M, JEIO TECH, Korea). In specified time intervals (after: 0, 5, 10, 15, 20, $30,45,60,90,120,150,180$, and $240 \mathrm{~min})$, samples $(5 \mathrm{~mL}$ ) were collected from the flasks using an automatic pipette to determine $\mathrm{P}_{-} \mathrm{PO}_{4}$ concentration in the solution. Experiments were performed in triplicate.

Analysis of $\mathrm{pH}$ effect on orthophosphate desorption efficiency. The chitosan hydrogel sorbents were pre-treated by orthophosphate sorption using the $\mathrm{NaH}_{2} \mathrm{PO}_{4}$ solution $\left(10 \mathrm{mg} \mathrm{P}-\mathrm{PO}_{4} / \mathrm{L}\right)$ with $\mathrm{pH}$ value optimal for each sorbent (established in point 3.3). The sorbent was used in a dose of $1 \mathrm{~g} / \mathrm{L}$. The sorption process was conducted on a multi-station shaker (150 r.p.m.). The contact time of the sorbent with the sorption solution was established in point 3.4 .

The hydrogel sorbents with sorbed orthophosphates were sifted on a screen and weighed (in $0.1 \mathrm{~g}$ d.m. portions) into empty conical flasks $(250 \mathrm{~mL})$. Next, $\mathrm{NaH}_{2} \mathrm{PO}_{4}$ solutions $(100 \mathrm{~mL})$ with $\mathrm{pH} 7-12$ (deionized water with $\mathrm{pH}$ corrected using $\mathrm{NaOH}$ solutions) were poured into the flasks, which were then placed on a shaker (150 r.p.m., oscillation amplitude $32 \mathrm{~mm})$. After $2 \mathrm{~h}$, samples $(10 \mathrm{~mL})$ were collected from each flask to determine the concentration of $\mathrm{P}_{-} \mathrm{PO}_{4}$ in desorption solutions. Solutions' $\mathrm{pH}$ was measured as well. Experiments were performed in triplicate.

Analysis of orthophosphate desorption kinetics. As in point 3.4, the hydrogel sorbent wase pretreated by orthophosphate sorption (at concentrations of $10 / 100 \mathrm{mg} \mathrm{P}-\mathrm{PO}_{4} / \mathrm{L}$ ) at the optimal sorption $\mathrm{pH}$ (established in point 3.3) and optimal contact time of the sorbent with the solution (established in point 3.4).

The sorbents prepared were weighed (in $2.0 \mathrm{~g} \mathrm{~d} . \mathrm{m}$. portions) into beakers $(2500 \mathrm{~mL})$. Next, $\mathrm{NaOH}$ solutions $(2000 \mathrm{~mL})$ with $\mathrm{pH} \mathrm{12/ \textrm {pH }} 13$ were added, and the beakers were placed on magnetic stirrers (150 r.p.m.). After 0, $5,10,15,20,30,45,60,90,120,150,180$, and $240 \mathrm{~min}$, samples $(5 \mathrm{~mL})$ were collected from the flasks to determine $\mathrm{P}_{-} \mathrm{PO}_{4}$ concentration in desorption solutions. Experiments were performed in triplicate.

Analysis of the efficiency of orthophosphate sorption/desorption cycles. The chitosan sorbents were weighed (in $5.0 \mathrm{~g}$ d.m. portions) into a series of flasks $(5000 \mathrm{~mL})$. Then, $\mathrm{NaH}_{2} \mathrm{PO}_{4}$ solutions with concentrations of 10/50/100 $\mathrm{mg} \mathrm{P}_{-} \mathrm{PO}_{4} / \mathrm{L}$ and an optimal sorption $\mathrm{pH}$ (established for each sorbent in point 3.3) were poured into the flasks. The flasks were then placed on a magnetic stirrer (150 r.p.m) for the optimal period of the sorption process (established in point 3.4). Afterward, the sorbents were separated from source solutions using laboratory screens. Then, samples $(100 \mathrm{~mL})$ of the source solutions were collected to determine $\mathrm{P}_{-} \mathrm{PO}_{4}$ concentration (later on, also $\mathrm{pH}$ and TDS were measured in these samples). The sifted sorbents were transferred to wide beakers $(1000 \mathrm{~mL})$. Then, $\mathrm{NaOH}$ solutions with $\mathrm{pH} 12 / \mathrm{pH} 13$ were added to the beakers, which were next placed on a multi-station magnetic stirrer (150 r.p.m.). After optimal desorption time (established in point $3.6)$, the sorbent was separated from the desorption solution (concentrate) using laboratory screens. Samples $(2 \mathrm{~mL})$ were collected from the concentrate to determine $\mathrm{P}_{-} \mathrm{PO}_{4}$ concentration. After completed desorption, also $\mathrm{pH}$ and TDS were measured in the concentrate.

The sorbent's batch separated from the concentrate in the first sorption/desorption cycle was used in the successive cycles. In the subsequent cycles, the sorption process was always performed in newly-prepared source solutions, whereas the desorption process was always conducted to the same desorption solution (concentrate). In each cycle, before the sorbent was added to the concentrate, its $\mathrm{pH}$ was corrected (to $\mathrm{pH} 12 / \mathrm{pH} 13$ ) using small amounts of $5 \mathrm{M} \mathrm{NaOH}$, to ensure that desorption would proceed at the same $\mathrm{pH}$ in the successive cycles. Between the cycles, the sorbents were neither rinsed nor regenerated in any way. The successive cycles were continued till the sorbents lost their capability for orthophosphate ions uptake from the source solutions (till concentrations of source solutions and concentrate were no longer changing). In total, 12 experimental series were conducted, differing in the concentration of the source solution $\left(10 / 50 / 100 \mathrm{mg} \mathrm{P}-\mathrm{PO}_{4} / \mathrm{L}\right), \mathrm{pH}$ of desorption solution (concentrate) ( $\mathrm{pH} \mathrm{12/pH} \mathrm{13),} \mathrm{and} \mathrm{sorbent} \mathrm{type} \mathrm{(CHs/CHs-ECH).}$

After the last effective cycle, analyses were conducted for the content of chlorides in the phosphate concentrate and for the dry residue of the concentrate, following Polish Standard PN-78/C-04541 (gravimetric method). 

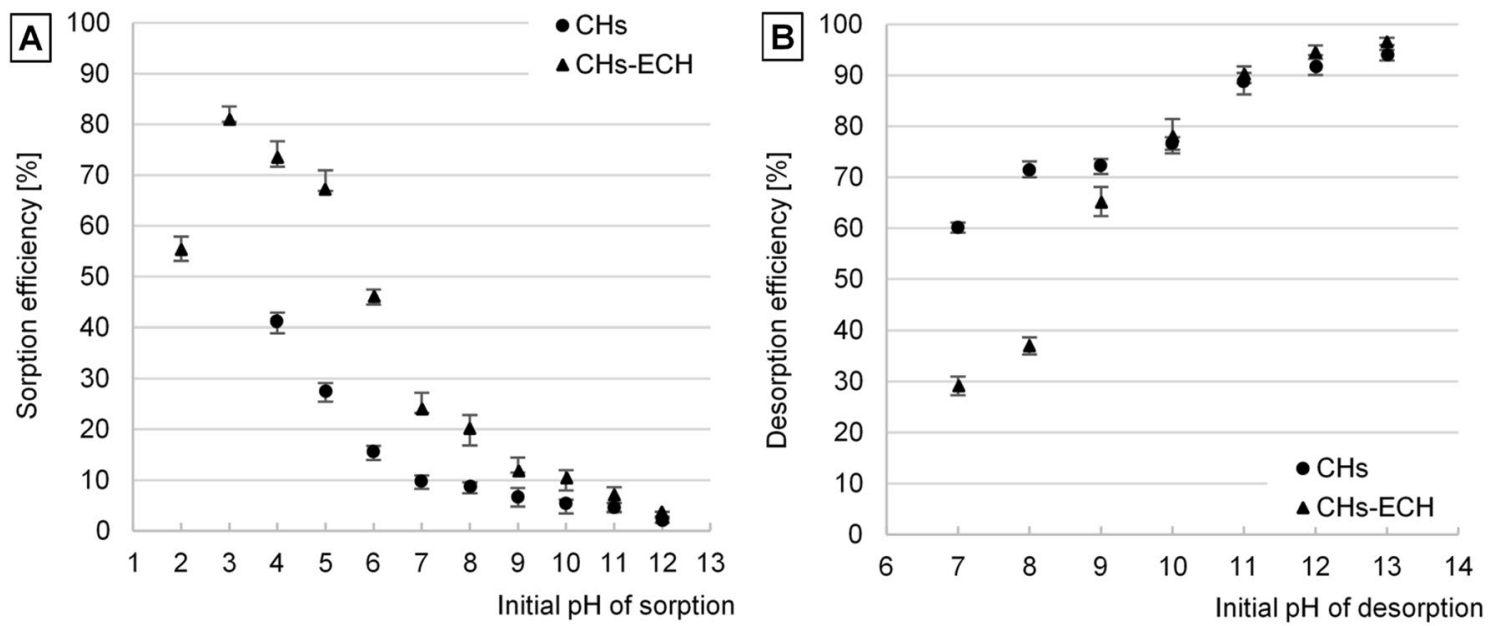

Figure 2. (A) Effect of $\mathrm{pH}$ on i- $\mathrm{PO}_{4}$ sorption efficiency, and (B) Effect of $\mathrm{pH}$ on i- $\mathrm{PO}_{4}$ desorption efficiency. Experiments were performed in triplicate $\left(\mathrm{C}_{\text {start }}=10 \mathrm{mg} \mathrm{P}-\mathrm{PO}_{4} / \mathrm{L}\right.$, sorbent dose $=1 \mathrm{~g}$ d.m. $/ \mathrm{L}, 150$ r.p.m., temp. $\left.22^{\circ} \mathrm{C}\right)$.

Physicochemical analyses. The content of orthophosphates was determined using the spectrophotometric method with ammonium molybdate (PN-EN ISO 6878:2006). The spectrophotometric analysis was carried out using a UV-3100 PC spectrophotometer (VWR Spectrophotometers, Canada). TDS and pH were determined in the source solutions, and the phosphate concentrate using a PL-700 ALS multifunctional tester (GOnDO Electronic, Taiwan). The content of chlorides in selected samples was determined using cuvette tests by $\mathrm{HACH}$.

Computation methods. The amount of phosphorus bound by the chitosan sorbents was computed from the formula:

$$
\mathrm{Q}=\left(\mathrm{C}_{\text {start }}-\mathrm{C}_{\mathrm{E}}\right) \times \mathrm{V} / \mathrm{m}
$$

where $\mathrm{Q}$-amount of bound phosphorus $\left[\mathrm{mg} \mathrm{P}-\mathrm{PO}_{4} / \mathrm{g}\right] ; \mathrm{C}_{\text {start}}-\mathrm{phosphorus} \mathrm{concentration} \mathrm{before} \mathrm{sorption} \mathrm{[mg}$

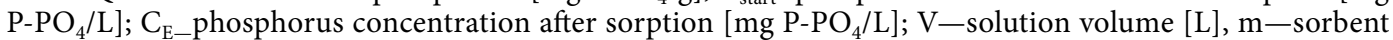
mass [g d.m.].

Phosphorus sorption and desorption kinetics were described using the pseudo-first order Eq. (2) and the pseudo-second order Eq. (3):

$$
\begin{aligned}
& \mathrm{dq} / \mathrm{dt}=\mathrm{k}_{1} \times\left(\mathrm{q}_{\mathrm{e}}-\mathrm{q}\right) \\
& \mathrm{dq} / \mathrm{dt}=\mathrm{k}_{2} \times\left(\mathrm{q}_{\mathrm{e}}-\mathrm{q}\right)^{2}
\end{aligned}
$$

where $\mathrm{k}_{1}$ constant in the pseudo-first order equation [L/min], $\mathrm{k}_{2}$ constant in the pseudo-second order equation $[\mathrm{L} / \mathrm{min}], \mathrm{q}_{\mathrm{e}}$ equilibrium amount of sorbed/desorbed phosphorus [mg $\left.\mathrm{P}_{-} \mathrm{PO}_{4} / \mathrm{g}\right]$; $\mathrm{q}-$ momentary amount of sorbed/desorbed phosphorus $\left[\mathrm{mg} \mathrm{P}-\mathrm{PO}_{4} / \mathrm{g}\right]$.

\section{Results and discussion}

Effect of pH on i-PO4 sorption and desorption. The efficiency of orthophosphate ion (i-PO4) sorption on the sorbents tested increased along with a decreasing initial $\mathrm{pH}$ value of the solution (Fig. 2A). The noncrosslinked chitosan hydrogel $(\mathrm{CHs})$ showed the highest sorption efficiency at $\mathrm{pH} 4$. At lower $\mathrm{pH}$ values $(\mathrm{pH}$ 2-3), it swelled and dissolved, due to which it was losing its ability to bind i-PO4. In turn, the chitosan hydrogel crosslinked with epichlorohydrin $(\mathrm{CHs}-\mathrm{ECH})$ was the most effective in binding i-PO4 at $\mathrm{pH} 3$. In turn, at $\mathrm{pH}$ 2 , its sorption efficiency decreased rapidly. In the case of $\mathrm{CHs}$ and $\mathrm{CHs}-\mathrm{ECH}$, the lowest sorption efficiency was determined at $\mathrm{pH} 12$ (Fig. 2A).

The high efficiency of orthophosphate sorption by the tested sorbents at low $\mathrm{pH}$ values was due to their basic nature induced by the presence of primary amine groups in chitosan's structure. At $\mathrm{pH}<7$, the $-\mathrm{NH}_{2}$ groups capable of easy protonation gained a positive charge $\left(-\mathrm{NH}_{2}+\mathrm{H}_{3} \mathrm{O}^{+} \rightarrow-\mathrm{NH}_{3}{ }^{+}+\mathrm{H}_{2} \mathrm{O}\right)$. The positively-charged amine groups of the sorbents were electrostatically attracting $\mathrm{i}-\mathrm{PO}_{4}$ (in the $\mathrm{pH}$ range of 3-7, mainly in the form of $\mathrm{H}_{2} \mathrm{PO}_{4}^{-}$), which significantly enhanced their sorption ${ }^{41}$. With the initial solution's $\mathrm{pH}$ increasing, the number of protonated amine groups decreased on the sorbent's surface, which was reflected in a reduced i-PO4 binding efficiency. At $\mathrm{pH}>10$, the chitosan hydrogels gained a strong negative charge, which additionally repulsed the orthophosphate ions (in the $\mathrm{pH}$ range of 10-12, mainly in the form of $\mathrm{HPO}_{4}{ }^{2-}$ ) from the sorbent's surface and hindered the sorption process ${ }^{42}$. The lower efficiency of orthophosphate sorption at $\mathrm{pH} 2$ could be caused by the $\mathrm{H}_{3} \mathrm{PO}_{4}$ form of most orthophosphates at $\mathrm{pH}$ 2. In this form (due to the "zero" electric charge) orthophosphates react severely less with protonated amine groups of chitosan than in the ionic forms ${ }^{43}$. The lower efficiency of 

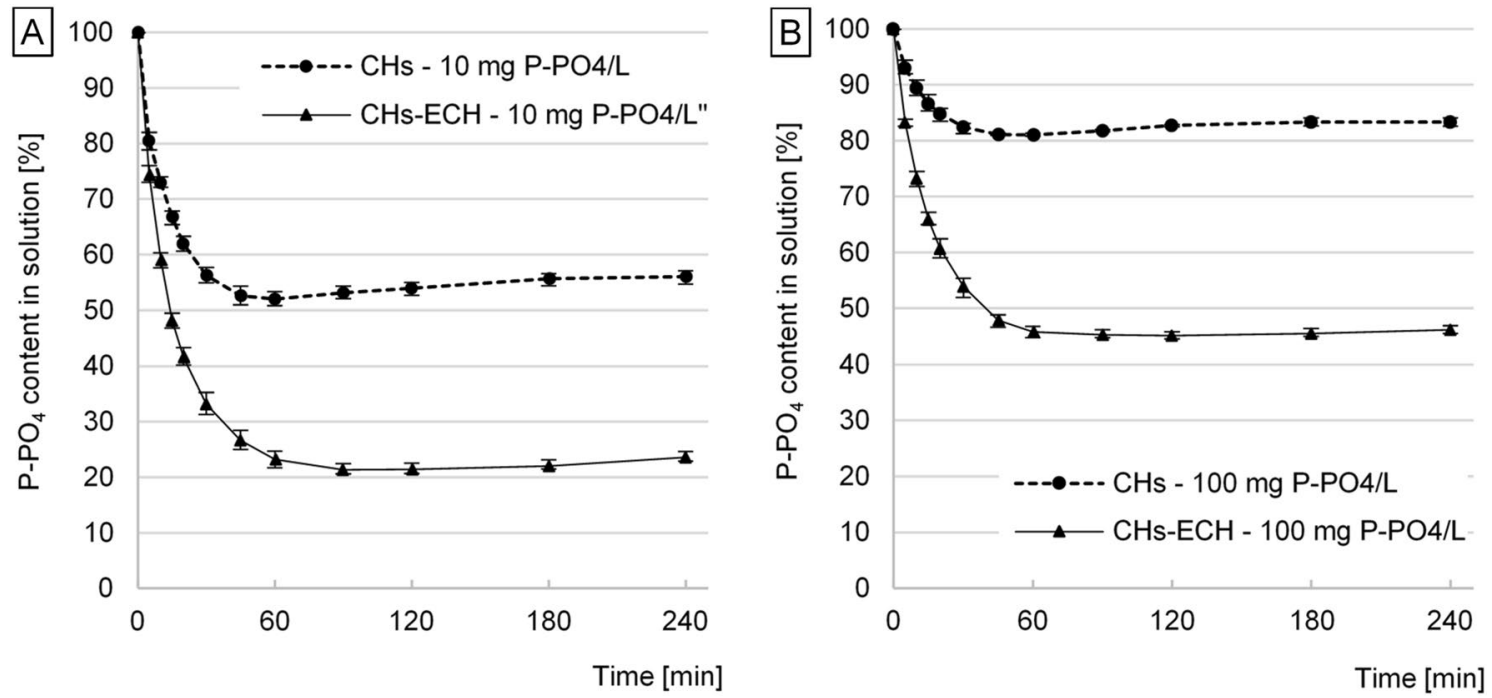

Figure 3. i- $\mathrm{PO}_{4}$ sorption kinetics. (A) initial concentration: $10 \mathrm{mg} \mathrm{P}_{-} \mathrm{PO}_{4} / \mathrm{L}$, (B) initial concentration: $100 \mathrm{mg}$ $\mathrm{P}_{-} \mathrm{PO}_{4} / \mathrm{L}$. Experiments were performed in triplicate $\left(\mathrm{C}_{\text {start }}=10 / 100 \mathrm{mg} \mathrm{P}-\mathrm{PO}_{4} / \mathrm{L}\right.$, sorbent dose $=1 \mathrm{~g}$ d.m. $/ \mathrm{L}$, sorption in $\mathrm{pH} 4$ for $\mathrm{CHs}$ and $\mathrm{pH} 3$ for $\mathrm{CHs}-\mathrm{ECH}, 150$ r.p.m., temp. $22^{\circ} \mathrm{C}$ ).

i- $\mathrm{PO}_{4}$ sorption on $\mathrm{CHs}-\mathrm{ECH}$ at $\mathrm{pH} 2$, compared to $\mathrm{CHs}-\mathrm{ECH}$ sorption efficiency at $\mathrm{pH} 3$, could be also due to a high number of chloride ions. The correction of orthophosphate solution's $\mathrm{pH}$ to $\mathrm{pH} 2$ required approximately a ten-fold higher volume of an $\mathrm{HCl}$ solution than its correction to $\mathrm{pH}$ 3. The $\mathrm{Cl}^{-}$ions competed with i- $\mathrm{PO}_{4}$ for free sorption sites, which could impair the sorption of $\mathrm{i}-\mathrm{PO}_{4}$. In turn, the higher sorption efficiency of $\mathrm{CHs}-\mathrm{ECH}$ than of $\mathrm{CHs}$ was due to the characteristic structure of the chitosan hydrogel crosslinked with epichlorohydrin. Granules of CHs-ECH are more hydrated, have larger surface, and better permeability of the hydrogel membrane compared to $\mathrm{CHs}$ granules, which resulted in their higher orthophosphate ion binding efficiency of ${ }^{40}$.

All subsequent experiments concerning i- $\mathrm{PO}_{4}$ sorption on $\mathrm{CH}$ s were conducted at $\mathrm{pH} 4$, whereas these concerning $\mathrm{i}-\mathrm{PO}_{4}$ sorption on $\mathrm{CHs}-\mathrm{ECH}-$ at $\mathrm{pH} 3$.

The efficiency of $\mathrm{i}-\mathrm{PO}_{4}$ desorption from the sorbents tested increased along with increasing $\mathrm{pH}$ of the desorption solution. The best desorption outcomes were achieved at $\mathrm{pH} 12-13$. The mean efficiency of i- $\mathrm{PO}_{4}$ desorption from $\mathrm{CHs}$ was $94.0 \%$ and that from $\mathrm{CHs}-\mathrm{ECH}$ was $96.6 \%$ (Fig. $2 \mathrm{~B}$ ).

Once sorbent had been introduced into a solution having a high $\mathrm{pH}$ value, the amine groups of chitosan lost their positive charge $\left(-\mathrm{NH}_{3}{ }^{+}+\mathrm{OH}^{-} \rightarrow-\mathrm{NH}_{2}+\mathrm{H}_{2} \mathrm{O}\right)$, whereas a major part of hydroxyl groups became deprotonated $\left(-\mathrm{OH}+\mathrm{OH}^{-} \rightarrow-\mathrm{O}^{-}+\mathrm{H}_{2} \mathrm{O}\right)$. Orthophosphate anions that were no longer electrostatically bound with chitosan's amine groups were pushed out outside hydrogel's structure due to the interaction with deprotonated hydroxyl groups.

At the initial $\mathrm{pH} 7-8$, the efficiency of $\mathrm{i}-\mathrm{PO}_{4}$ desorption from $\mathrm{CHs}-\mathrm{ECH}$ was significantly lower compared to $\mathrm{CHs}$, likely because of the various effects of the sorbents on the $\mathrm{pH}$ value of solutions they were in contact with and also because of various $\mathrm{pH}_{\mathrm{PZC}}$ values ${ }^{39}$.

Both $\mathrm{CHS}$ and $\mathrm{CHs}-\mathrm{ECH}$ changed the $\mathrm{pH}$ value of the sorption and desorption solutions. The system tended to reach a $\mathrm{pH}$ value approximating the $\mathrm{pH}_{\mathrm{PZC}}$ ( $\mathrm{PZC}$ - point of zero charge) of the sorbents tested. The $\mathrm{pH}_{\mathrm{PZC}}$ determined for $\mathrm{CHs}$ was $\mathrm{pH}_{\mathrm{PZC}}=7.8$ and that determined for $\mathrm{CHs}-\mathrm{ECH}$ was $\mathrm{pH}_{\mathrm{PZC}}=6.7$ (Supplement 2). Analyses concerning the effect of hydrogels on solutions' $\mathrm{pH}$ and determination of sorbents' $\mathrm{pH}_{\mathrm{PZC}}$ were described in Supplement 2.

i- $\mathrm{PO}_{4}$ sorption and desorption kinetics. Regardless of the initial i- $\mathrm{PO}_{4}$ concentration, the time after which the amount of bound orthophosphates was the highest reached $60 \mathrm{~min}$ for $\mathrm{CHs}$ and $90 \mathrm{~min}$ for $\mathrm{CHs}-\mathrm{ECH}$ (Fig. 3). After $60 \mathrm{~min}$ of sorption with $\mathrm{CHs}$, the i- $\mathrm{PO}_{4}$ concentration in the source solution began to increase, indicating orthophosphate desorption. During sorption with $\mathrm{CHs}-\mathrm{ECH}$, the onset of $\mathrm{i}-\mathrm{PO}_{4}$ release to the source solution was recorded after $120 \mathrm{~min}$ of the process. However, the number of lost orthophosphate ions (desorbed by $\mathrm{CHs}-\mathrm{ECH}$ ) was lower than in the case of $\mathrm{CHs}$.

During the sorption process, the positive charge that was initially accumulated on the surface of a hydrogel granule began to be evenly distributed across the whole hydrogel's volume. Because $\mathrm{i}-\mathrm{PO}_{4}$ ions are less capable for penetrating hydrogel' structure than protons and hydronium ions, presumably most of them were bound in the outer hydrogel layers. Because the $\mathrm{pH}$ value increased over the sorption process, the force of electrostatic attraction between chitosan chains and orthophosphate ions located on the sorbent's surface decreased. Consequently, only a small part of earlier bound orthophosphate ions could be released to the source solution ${ }^{16}$.

In the case of $\mathrm{CHs}-\mathrm{ECH}$, the longer sorption time and the longer time after which i- $\mathrm{PO}_{4}$ started to be released to the source solution could be associated with the lower $\mathrm{pH}_{\mathrm{PZC}}$ of the sorbent and with the lower initial sorption $\mathrm{pH}$ (pH3 for $\mathrm{CHs}-\mathrm{ECH}$ and $\mathrm{pH} 4$ for $\mathrm{CHs}$ ). At $\mathrm{pH} 3, \mathrm{CHs}-\mathrm{ECH}$ showed higher i- $\mathrm{PO}_{4}$ binding ability than $\mathrm{CHs}$ at $\mathrm{pH} 4$; however, a higher number of ions penetrating to the hydrogel granule's interior extended the sorption 


\begin{tabular}{|c|c|c|c|c|c|c|c|c|c|c|c|}
\hline \multirow[b]{2}{*}{ Sorbent } & \multirow{2}{*}{$\begin{array}{l}{\mathrm{P}-\mathrm{PO}_{4} \text { conc. }}_{\left(\mathrm{mg} \mathrm{P}-\mathrm{PO}_{4} / \mathrm{L}\right)}\end{array}$} & \multicolumn{4}{|c|}{ Pseudo-first order model (non-linear) } & \multicolumn{4}{|c|}{ Pseudo-second order model (non-linear) } & \multirow{2}{*}{$\begin{array}{l}\text { Exp. data } \\
q_{e, c a l}(\mathrm{mg} / \mathrm{g}) \\
\end{array}$} & \\
\hline & & $k_{1}(1 / \min )$ & $\mathbf{q}_{\mathrm{e}, \mathrm{cal}}(\mathrm{mg} / \mathrm{g})$ & $\mathbf{R}^{2}$ & $\chi^{2}$ & $\mathrm{k}_{2}\left(\mathrm{~g} / \mathrm{mg}^{*} \mathrm{~min}\right)$ & $\mathbf{q}_{\mathrm{e}, \mathrm{cal}}(\mathrm{mg} / \mathrm{g})$ & $\mathbf{R}^{2}$ & $\chi^{2}$ & & \\
\hline \multicolumn{12}{|c|}{ Kinetic parameters of i-PO4 sorption } \\
\hline \multirow{2}{*}{$\mathrm{CHs}$} & 10 & 0.0861 & 4.75 & 0.9939 & 0.0423 & 0.0199 & 5.47 & 0.9913 & 0.0611 & 4.70 & \\
\hline & 100 & 0.0855 & 18.81 & 0.9969 & 0.0828 & 0.0049 & 21.75 & 0.9853 & 0.3039 & 18.85 & \\
\hline \multirow{2}{*}{ CHs-ECH } & 10 & 0.0736 & 7.71 & 0.9977 & 0.0235 & 0.0093 & 9.13 & 0.9968 & 0.0288 & 7.86 & \\
\hline & 100 & 0.0656 & 54.77 & 0.9986 & 0.1765 & 0.0011 & 55.80 & 0.9959 & 0.2591 & 54.75 & \\
\hline \multirow[b]{2}{*}{ Sorbent } & \multirow[b]{2}{*}{$\begin{array}{l}\text { Conc. of } \\
\text { source solut.* }\end{array}$} & \multirow[b]{2}{*}{$\begin{array}{l}\text { Des. pH } H^{* *} \\
\text { (pH) }\end{array}$} & \multicolumn{4}{|c|}{ Pseudo-first order model (non-linear) } & \multicolumn{4}{|c|}{ Pseudo-second order model (non-linear) } & Exp. data \\
\hline & & & $\begin{array}{l}\mathbf{k}_{1} \text { (desorpt.) (1/ } \\
\mathbf{m i n})\end{array}$ & \begin{tabular}{|l}
$\mathbf{q}_{\mathrm{e}, \text { cal }}$ (desorpt.) \\
$(\mathbf{m g} / \mathbf{g})$
\end{tabular} & $\mathbf{R}^{2}$ & $\chi^{2}$ & $\begin{array}{l}\mathbf{k}_{2} \text { (desorpt.) }(\mathbf{g} / \\
\left.\mathbf{m g}^{\star} \mathbf{m i n}\right)\end{array}$ & \begin{tabular}{|l}
$\mathbf{q}_{\text {e,cal }}$ (desorpt.) \\
(mg/g)
\end{tabular} & $\mathbf{R}^{2}$ & $\chi^{2}$ & $\begin{array}{l}\mathbf{q}_{\text {e,cal }} \text { (desorpt. } \\
(\mathbf{m g} / \mathbf{g})\end{array}$ \\
\hline \multicolumn{12}{|c|}{ Kinetic parameters of i-PO4 desorption } \\
\hline \multirow{6}{*}{$\mathrm{CHs}$} & \multirow{3}{*}{10} & 11 & 0.0985 & 4.19 & 0.9972 & 0.0219 & 0.0271 & 4.78 & 0.9950 & 0.0225 & 4.22 \\
\hline & & 12 & 0.2803 & 4.21 & 0.9959 & 0.0031 & 0.1337 & 4.44 & 0.9920 & 0.0161 & 4.29 \\
\hline & & 13 & 0.4027 & 4.35 & 0.9967 & 0.0119 & 0.2988 & 4.43 & 0.9946 & 0.0222 & 4.40 \\
\hline & \multirow{3}{*}{100} & 11 & 0.0669 & 15.92 & 0.9995 & 0.0174 & 0.0039 & 16.12 & 0.9940 & 0.1305 & 15.93 \\
\hline & & 12 & 0.2024 & 15.89 & 0.9992 & \begin{tabular}{|l|}
0.0122 \\
\end{tabular} & 0.0212 & 17.06 & 0.9933 & 0.1112 & 16.08 \\
\hline & & 13 & 0.3282 & 16.30 & 0.9943 & 0.0083 & 0.0521 & 16.74 & 0.9982 & 0.0133 & 16.56 \\
\hline \multirow{6}{*}{ CHs-ECH } & \multirow{3}{*}{10} & 11 & 0.0763 & 6.97 & 0.9956 & 0.0697 & 0.0147 & 7.61 & 0.9891 & 0.0847 & 7.07 \\
\hline & & 12 & 0.1117 & 7.23 & 0.9940 & 0.0795 & 0.0239 & 7.73 & 0.9921 & 0.0747 & 7.30 \\
\hline & & 13 & 0.1339 & 7.34 & 0.9977 & \begin{tabular}{|l|}
0.0205 \\
\end{tabular} & \begin{tabular}{|l|}
0.0297 \\
\end{tabular} & 7.79 & 0.9900 & 0.0741 & 7.42 \\
\hline & \multirow{3}{*}{100} & 11 & 0.0706 & 44.60 & 0.9963 & 0.4795 & 0.0021 & 48.96 & 0.9887 & 0.5000 & 45.25 \\
\hline & & 12 & 0.1115 & 45.71 & 0.9966 & 0.2733 & 0.0038 & 48.89 & 0.9888 & 0.4607 & 46.50 \\
\hline & & 13 & 0.1195 & 46.82 & 0.9954 & 0.3058 & 0.0041 & 49.91 & 0.9884 & 0.4398 & 47.50 \\
\hline
\end{tabular}

Table 1. Parameters of i- $\mathrm{PO}_{4}$ sorption and desorption kinetics determined from the pseudo-first order model and pseudo-second order model. ${ }^{\star}$ Concentration of source solution (used for sorbent preparation) (mg $\left.\mathrm{P}_{-} \mathrm{PO}_{4} / \mathrm{L}\right)$, ${ }^{*}$ Desorption $\mathrm{pH} .\left(\mathrm{C}_{\text {start }}=10 / 100 \mathrm{mg} \mathrm{P}-\mathrm{PO}_{4} / \mathrm{L}\right.$, sorbent dose $=1 \mathrm{~g}$ d.m. $/ \mathrm{L}$, sorption in $\mathrm{pH} 4$ for $\mathrm{CHs}$ and $\mathrm{pH} 3$ for $\mathrm{CHs}-\mathrm{ECH}$, desorption at $\mathrm{pH} 11-13,150$ r.p.m., temp. $22^{\circ} \mathrm{C}$.).

process. In the experimental series with $\mathrm{CHs}-\mathrm{ECH}$, an increase in solution's $\mathrm{pH}$ during i- $\mathrm{PO}_{4}$ sorption was not that high as in the case of $\mathrm{CHs}$, which caused retardation and lesser intensity of ion release. After too long contact of the sorbent with the source solution, the phenomenon of orthophosphate desorption was also observed during nutrients removal from multi-component solutions ${ }^{17}$.

The kinetics of $\mathrm{i}-\mathrm{PO}_{4}$ sorption on chitosan sorbents was described using pseudo-first order and pseudo-second order models (Table 1). A better fit of the pseudo-first order model to experimental data (higher values of $\mathrm{R}^{2}$ and smaller values of Chi square $-\chi^{2}$ ) is indicative of the typical physical nature of the process (physical sorption). The intensity of $\mathrm{i}-\mathrm{PO}_{4}$ sorption on $\mathrm{CHs}$ and $\mathrm{CHs}-\mathrm{ECH}$ was higher at the higher initial concentrations of the orthophosphate ions (Table 1), which can be explained by a higher probability of i- $\mathrm{PO}_{4}$ collisions with chitosan's sorption centers. The higher number of orthophosphate ions additionally shifted the point of the osmotic equilibrium between $\mathrm{i}-\mathrm{PO}_{4}$ concentration in the hydrogel and source solution in the system, which ultimately led to a higher absorption of the sorbate. $\mathrm{CHs}-\mathrm{ECH}$ was far more effective in $\mathrm{i}-\mathrm{PO}_{4}$ sorption than $\mathrm{CHs}$, presumably due its specific characteristics including a larger specific surface, better permeability of the hydrogel membrane, and lower sorption $\mathrm{pH}(\mathrm{pH} 3)^{40}$.

The time needed to reach the highest $\mathrm{i}-\mathrm{PO}_{4}$ desorption depended on sorbent type, the concentration of the source solution used to prepare the sorbent, and $\mathrm{pH}$ of the desorption solution. In the experimental series in which CHs was prepared in the source solution with $\mathrm{C}_{\text {start }}=10 \mathrm{mg} \mathrm{P}-\mathrm{PO}_{4} / \mathrm{L}$, the maximum i- $\mathrm{PO}_{4}$ concentration in the desorption solution was achieved after $30 \mathrm{~min}$ at desorption process $\mathrm{pH} 11$ and after $45 \mathrm{~min}$ at $\mathrm{pH}$ 12-13 (Fig. 4A). In turn, in the experimental series in which $\mathrm{CHs}$ was prepared in the source solution with $\mathrm{C}_{\text {start }}=100 \mathrm{mg} \mathrm{P}-\mathrm{PO}_{4} / \mathrm{L}$, desorption times were longer and reached $60 \mathrm{~min}$ at desorption $\mathrm{pH} 11$ and $45 \mathrm{~min}$ at desorption $\mathrm{pH} 12$ and $\mathrm{pH} 13$ (Fig. 4C). In the case of $\mathrm{CHs}-\mathrm{ECH}$ prepared in the solution with $\mathrm{C}_{\text {start }}=10 \mathrm{mg}$ $\mathrm{P}_{-} \mathrm{PO}_{4} / \mathrm{L}$, desorption times were from $60 \mathrm{~min}$ at $\mathrm{pH} 12$ and $\mathrm{pH} 13$ to $90 \mathrm{~min}$ at $\mathrm{pH} 11$. With CHs-ECH prepared in the source solution with $\mathrm{C}_{\text {start }}=100 \mathrm{mg} \mathrm{P}-\mathrm{PO}_{4} / \mathrm{L}$, desorption times noted at $\mathrm{pH} 12$ and 13 elongated to $90 \mathrm{~min}$ (Fig. 4B, D).

At higher $\mathrm{pH}$ values of the desorption process, the sorbents had a higher total negative charge. The stronger electrostatic repulsion between chitosan chains and orthophosphate anions significantly shortened desorption time.

Differences between the duration of orthophosphate desorption from the sorbents prepared in source solutions with different i-PO4 concentrations $\left(10\right.$ and $\left.100 \mathrm{mg} \mathrm{P}-\mathrm{PO}_{4} / \mathrm{L}\right)$ are probably due to the various amounts of orthophosphate ions bound. At the source solution concentration of $\mathrm{C}_{\text {start }}=10 \mathrm{mg} \mathrm{P}-\mathrm{PO}_{4} / \mathrm{L}, \mathrm{Q}_{\max }$ was $4.70 \mathrm{mg} / \mathrm{g}$ (for CHs) and $7.86 \mathrm{mg} / \mathrm{g}$ (for CHs-ECH), whereas at the concentration of $\mathrm{C}_{\text {start }}=100 \mathrm{mg} \mathrm{P}-\mathrm{PO}_{4} / \mathrm{L}, \mathrm{Q}_{\max }$ reached $18.85 \mathrm{mg} / \mathrm{g}$ (for CHs) and $54.75 \mathrm{mg} / \mathrm{g}$ (for CHs-ECH) (Table 1). The higher amount of bound i-PO4 ions caused an extended time of their desorption. 

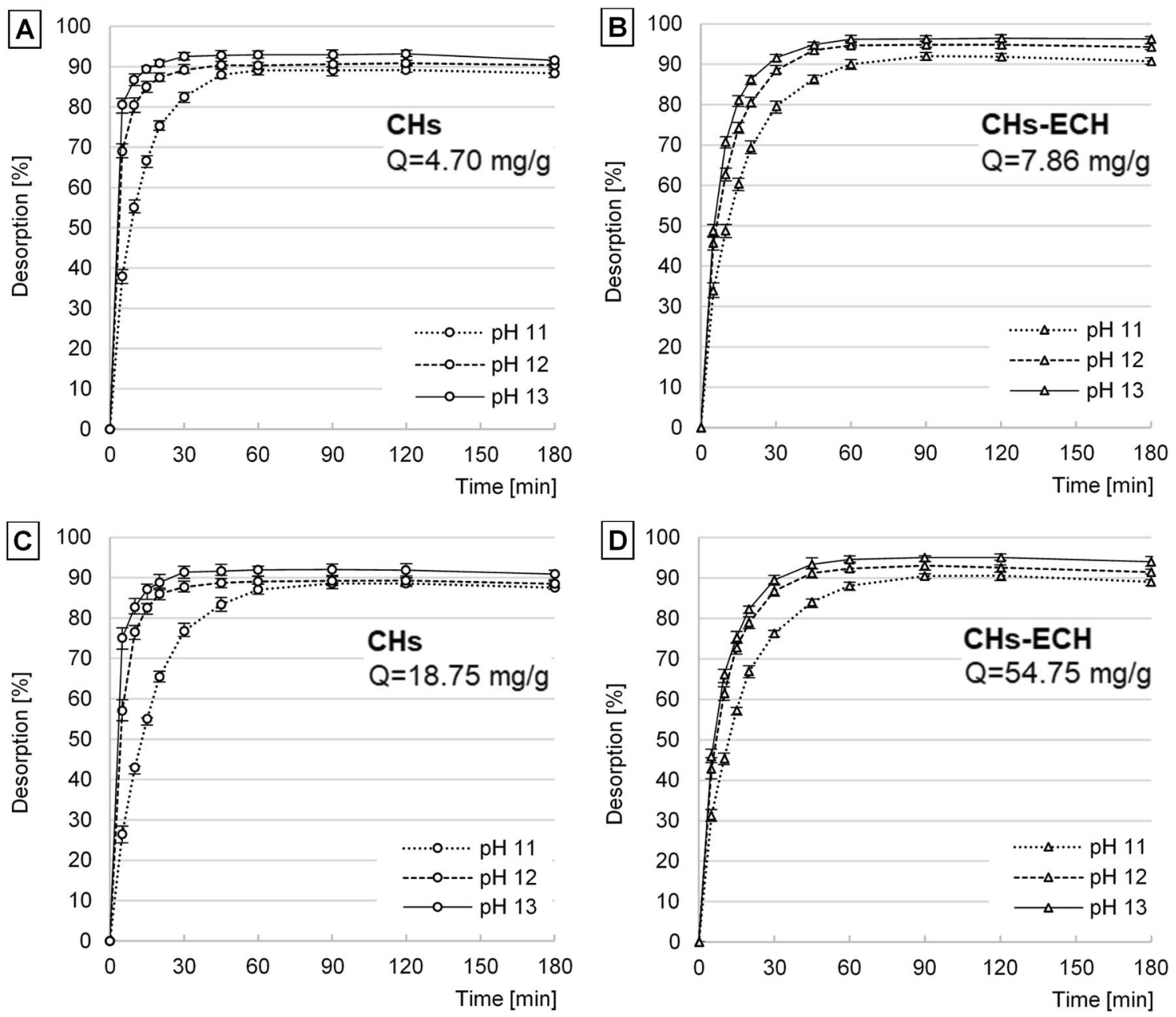

Figure 4. i-PO4 desorption kinetics at $\mathrm{pH}$ 11-13. (A) $\mathrm{CHs}-$ sorbent prepared at the source solution concentration of $10 \mathrm{mg} \mathrm{P}-\mathrm{PO}_{4} / \mathrm{L}(\mathrm{Q}=4.70 \mathrm{mg} / \mathrm{g})$. (B) $\mathrm{CHs}-\mathrm{ECH}$-sorbent prepared at the source solution concentration of $10 \mathrm{mg} \mathrm{P}-\mathrm{PO}_{4} / \mathrm{L}(\mathrm{Q}=7.86 \mathrm{mg} / \mathrm{g})$. (C) $\mathrm{CHs}$-sorbent prepared at the source solution concentration of $100 \mathrm{mg} \mathrm{P}-\mathrm{PO}_{4} / \mathrm{L}(\mathrm{Q}=18.85 \mathrm{mg} / \mathrm{g})$. (D) $\mathrm{CHs}-\mathrm{ECH}$-sorbent prepared at the source solution concentration of $100 \mathrm{mg} \mathrm{P}-\mathrm{PO}_{4} / \mathrm{L}(\mathrm{Q}=54.75 \mathrm{mg} / \mathrm{g})$. Experiments were performed in triplicate. (Sorbent dose $=1 \mathrm{~g}$ d.m. $/ \mathrm{L}$, desorption at $\mathrm{pH} 11-13,150$ r.p.m., temp. $\left.22^{\circ} \mathrm{C}\right)$.

A similar explanation can be provided for differences between i-PO4 desorption times from CHs and CHsECH. Before desorption, the crosslinked sorbent possessed a significantly higher number of sorbed orthophosphate ions than $\mathrm{CHs}$, which could prolong the desorption process. Besides, the longer i-PO4 desorption from $\mathrm{CHs}-\mathrm{ECH}$ could be affected by the characteristic swollen structure of the crosslinked hydrogel ${ }^{40}$ and lower $\mathrm{pH}$ used during sorbent preparation. Due to the greater diameter of $\mathrm{CHs}-\mathrm{ECH}$ granules saturated with orthophosphate ions and also because of chloride ions $(\mathrm{pH}$ correction with $\mathrm{HCl}$ ), the time needed for a change in the charge of the chitosan chains in deeper sorbent layers was considerably longer. This could, additionally, retard desorption of i-PO4 located inside the sorbent.

In most of the experimental series, a small decrease was noted in i-PO4 concentration in the desorption solution after $120 \mathrm{~min}$, which could be associated with a partial decrease in desorption solution $\mathrm{pH}$ and a change in the charge on sorbent's surface. The lower total negative charge on sorbent's surface probably influenced the shift of osmotic equilibrium of the system. As a result, a small part of earlier desorbed orthophosphate ions was again bound with the chitosan hydrogel.

Like sorption kinetics, the kinetics of desorption process was described with the pseudo-first order and pseudo-second order models (Table 1). The best fit of experimental data to the pseudo-first order model (higher values of $\mathrm{R}^{2}$ and smaller values of Chi square $-\chi^{2}$ ) confirms that desorption process's mechanism was based on physical interactions.

The intensity of i-PO4 desorption from the sorbents tested increased along with $\mathrm{pH}$ increase (Fig. 4, k1 values-Table 1). Even though the $\mathrm{pH}$ value of desorption solutions had a significant effect on i-PO4 desorption rate, the effect of $\mathrm{pH}$ ( $\mathrm{pH}$ 11-13) on the ultimate amount of i-PO4 desorbed was relatively small (Table 1).

In the experimental series with the same $\mathrm{pH}$ value of the desorption solution, the percentage efficiency of i-PO4 desorption from CHs and CHs-ECH was similar (Fig. 4). However, CHs-ECH's capability for binding 

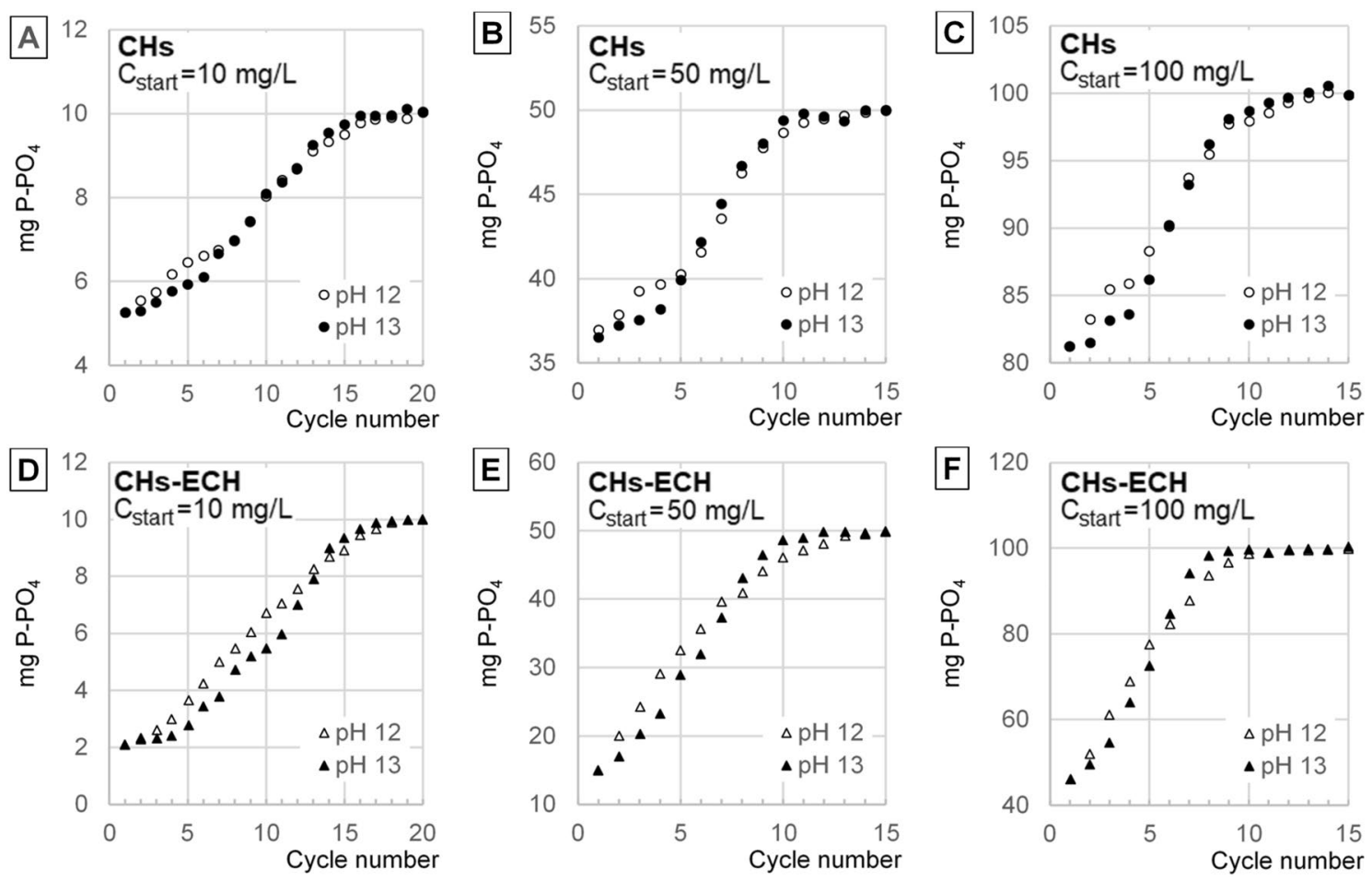

Figure 5. Concentrations of i-PO4 in source solutions $\left(\mathrm{C}_{\text {start }}=10-100 \mathrm{mg} \mathrm{P}_{-} \mathrm{PO}_{4} / \mathrm{L}\right)$ after sorption in the successive cycles using $\mathrm{CHs}$ and $\mathrm{CHs}-\mathrm{ECH}:(\mathbf{A}) \mathrm{CHs}, \mathrm{C}_{\text {start }}=10 \mathrm{mg} \mathrm{P}-\mathrm{PO}_{4} / \mathrm{L},(\mathbf{B}) \mathrm{CHs}, \mathrm{C}_{\text {start }}=50 \mathrm{mg} \mathrm{P}-\mathrm{PO}_{4} / \mathrm{L}$, (C) $\mathrm{CHs}, \mathrm{C}_{\text {start }}=100 \mathrm{mg} \mathrm{P}-\mathrm{PO}_{4} / \mathrm{L},(\mathrm{D}) \mathrm{CHs}-\mathrm{ECH}, \mathrm{C}_{\text {start }}=10 \mathrm{mg} \mathrm{P}-\mathrm{PO}_{4} / \mathrm{L},(\mathrm{E}) \mathrm{CHs}-\mathrm{ECH}, \mathrm{C}_{\text {start }}=50 \mathrm{mg} \mathrm{P}-\mathrm{PO}_{4} / \mathrm{L}$, (F) CHs-ECH, $\mathrm{C}_{\text {start }}=100 \mathrm{mg} \mathrm{P}-\mathrm{PO}_{4} / \mathrm{L}$. (Sorbent dose $=1 \mathrm{~g}$ d.m. $/ \mathrm{L}$, sorption in $\mathrm{pH} 4$ for $\mathrm{CHs}$ and $\mathrm{pH} 3$ for CHs$\mathrm{ECH}$, desorption at $\mathrm{pH} 12$ and 13,150 r.p.m., temp. $\left.22^{\circ} \mathrm{C}\right)$.

more i-PO4 from the source solutions compared to $\mathrm{CHs}$ resulted in ultimately higher concentrations of the orthophosphates in desorption solutions (Table 1).

The sorption/desorption time established in the successive experimental series reached $60 \mathrm{~min} / 60 \mathrm{~min}$ for $\mathrm{CHs}$ and $90 \mathrm{~min} / 90 \mathrm{~min}$ for $\mathrm{CHs}-\mathrm{ECH}$.

Effect of sorbent time and source solution concentration on the efficiency of cyclic i-PO4 sorption/desorption. The concentration of orthophosphate ions increased in source solutions with each sorption cycle, indicting decreasing i-PO4 sorption efficiency on the sorbents decreased in the successive cycles (sorption/desorption). The number of cycles in which the sorbents could bind i-PO4 decreased along with an increasing concentration of the source solution. The sorbents tested were losing their sorptive abilities faster in the systems with higher desorption $\mathrm{pH}$ (Figs. 5, 6).

In the first cycles, i-PO4 sorption from the source solution was more efficient in the systems where desorption proceeded at higher $\mathrm{pH}$ ( $\mathrm{pH} 13)$. In the last cycles, however, the efficiency of orthophosphate binding from the source solution was higher in the series with lower desorption $\mathrm{pH}$ ( $\mathrm{pH}$ 12) (Figs. 5, 6).

The concentration of $\mathrm{i}-\mathrm{PO} 4$ in the orthophosphate concentrate increased with each sorption/desorption cycle, but desorption efficiency decreased. The concentrate's concentration increased until the sorbent batch lost its sorptive ability.

The $\mathrm{pH}$ value of the desorption process had a moderate effect on the concentration of orthophosphates in the concentrate (Fig. 6). In the initial cycles, the i-PO4 concentration was higher in the concentrates with $\mathrm{pH}$ 13, indicating a higher desorption efficiency than in the systems with $\mathrm{pH} 12$. However, in the successive cycles, the efficiency of i-PO4 desorption in the systems with the concentrate having $\mathrm{pH} 13$ decreased significantly faster than in these with the concentrate having $\mathrm{pH}$ 12. Ultimately, in the experimental series with desorption conducted at $\mathrm{pH} \mathrm{12,} \mathrm{the} \mathrm{maximum} \mathrm{concentration} \mathrm{of} \mathrm{orthophosphates} \mathrm{was} \mathrm{higher} \mathrm{than} \mathrm{in} \mathrm{the} \mathrm{systems} \mathrm{with} \mathrm{pH}$ 13. The differences in the maximum concentrations between orthophosphate concentrates with $\mathrm{pH} 12$ and $\mathrm{pH}$ 13 were, however, small (Fig. 6).

The concentrations of the concentrates increased along with an increasing concentration of the source solutions of $\mathrm{i}-\mathrm{PO} 4$. The concentrations of $\mathrm{i}-\mathrm{PO} 4$ in the concentrate were also higher in the experimental series with $\mathrm{CHs}-\mathrm{ECH}$ used as the carrier of these ions. The maximum concentration of orthophosphates obtained in the concentrate ranged from $150.0 \mathrm{mg} / \mathrm{L}(\mathrm{CHs})$ and $304.2 \mathrm{mg} / \mathrm{L}(\mathrm{CHs}-\mathrm{ECH})$ at a source solution concentration of $\mathrm{C}_{\text {start }}=10 \mathrm{mg} \mathrm{P}-\mathrm{PO}_{4} / \mathrm{L}$, to $332.0 \mathrm{mg} / \mathrm{L}(\mathrm{CHs})$ and $971.6 \mathrm{mg} / \mathrm{L}(\mathrm{CHs}-\mathrm{ECH})$ at a source solution concentration of $\mathrm{C}_{\text {start }}=100 \mathrm{mg} \mathrm{P}-\mathrm{PO}_{4} / \mathrm{L}$ (Fig. 6; Table 2).

The efficiency of i-PO4 desorption to the concentrate decreased with each cycle due to increasing concentrations of orthophosphates and chlorides in the concentrate. Desorption proceeded in the successive cycles until 

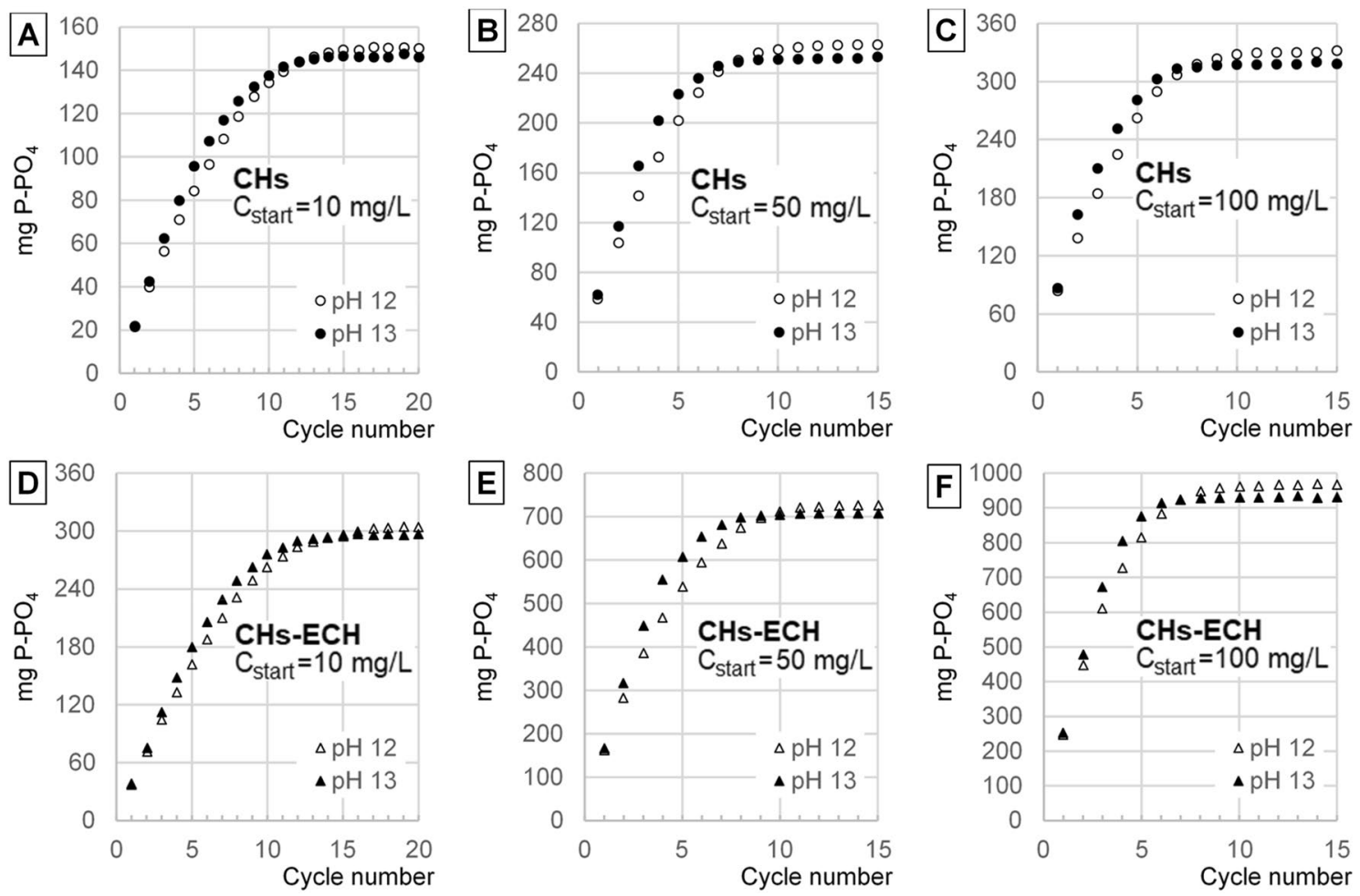

Figure 6. Concentrations of $\mathrm{i}-\mathrm{PO} 4$ in the concentrate after desorption in the successive cycles: (A) $\mathrm{CHs}$,

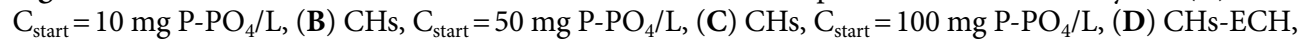
$\mathrm{C}_{\text {start }}=10 \mathrm{mg} \mathrm{P}-\mathrm{PO}_{4} / \mathrm{L}$, (E) CHs-ECH, $\mathrm{C}_{\text {start }}=50 \mathrm{mg} \mathrm{P}-\mathrm{PO}_{4} / \mathrm{L}$, (F) CHs-ECH, $\mathrm{C}_{\text {start }}=100 \mathrm{mg} \mathrm{P}-\mathrm{PO}_{4} / \mathrm{L}$. (Sorbent dose $=1 \mathrm{~g}$ d.m. $/ \mathrm{L}$, sorption in $\mathrm{pH} 4$ for $\mathrm{CHs}$ and $\mathrm{pH} 3$ for $\mathrm{CHs}-\mathrm{ECH}$, desorption at $\mathrm{pH} 12$ and 13, Source solution volume to concentrate volume ratio-5:1, 150 r.p.m., temp. $22^{\circ} \mathrm{C}$ ).

\begin{tabular}{|c|c|c|c|c|c|c|c|c|}
\hline Sorbent & $\begin{array}{l}\text { Conc. of P-PO4 } \\
\text { in source solution } \\
(\mathrm{mg} / \mathrm{L})\end{array}$ & $\begin{array}{l}\text { pH during } \\
\text { desorption }\end{array}$ & $\begin{array}{l}\text { Conc. Of P-PO4 } \\
\text { in concentrate } \\
(\mathrm{mg} / \mathrm{L})\end{array}$ & $\begin{array}{l}\text { Chloride conc. } \\
\text { (mg Cl} / / \mathrm{L})\end{array}$ & $\begin{array}{l}\text { TDS in } \\
\text { concentrate (mg } \\
\left.\mathrm{Cl}^{-} / \mathrm{L}\right)\end{array}$ & $\mathrm{pH}$ of concentrate & $\begin{array}{l}\text { Dry residue* } \\
(\mathrm{mg} / \mathrm{L})\end{array}$ & $\begin{array}{l}\text { P-PO4 content in } \\
\text { the sediment }{ }^{* *} \\
(\%)\end{array}$ \\
\hline \multirow{6}{*}{$\mathrm{CHs}$} & \multirow{2}{*}{10} & $\mathrm{pH} 12$ & 150.01 & 16.5 & 805 & 11.98 & 842.19 & 17.81 \\
\hline & & $\mathrm{pH} 13$ & 146.02 & 20.9 & 1111 & 12.99 & 1196.2 & 12.21 \\
\hline & \multirow{2}{*}{50} & $\mathrm{pH} 12$ & 262.84 & 11.3 & 1259 & 11.76 & 1390.86 & 18.90 \\
\hline & & $\mathrm{pH} 13$ & 252.35 & 15.0 & 1489 & 12.99 & 1625.11 & 15.53 \\
\hline & \multirow{2}{*}{100} & $\mathrm{pH} 12$ & 331.98 & 9.47 & 1556 & 11.67 & 1674.11 & 19.83 \\
\hline & & pH 13 & 318.31 & 16.4 & 1788 & 12.92 & 1889.26 & 16.85 \\
\hline \multirow{6}{*}{ CHs-ECH } & \multirow{2}{*}{10} & $\mathrm{pH} 12$ & 304.24 & 326 & 1801 & 9.38 & 1896.88 & 16.04 \\
\hline & & $\mathrm{pH} 13$ & 296.96 & 377 & 2599 & 12.9 & 2670.5 & 11.12 \\
\hline & \multirow{2}{*}{50} & $\mathrm{pH} 12$ & 723.84 & 191 & 4106 & 8.56 & 4187.52 & 17.29 \\
\hline & & pH 13 & 706.39 & 249 & 4682 & 12.69 & 4819.46 & 14.66 \\
\hline & \multirow{2}{*}{100} & pH 12 & 971.61 & 106 & 5321 & 8.42 & 5477.32 & 17.74 \\
\hline & & $\mathrm{pH} 13$ & 931.06 & 149 & 5896 & 12.59 & 6049.74 & 15.39 \\
\hline
\end{tabular}

Table 2. Parameters of orthophosphate concentrate in the last sorption/desorption cycle. ${ }^{\star}$ Dry residue (after concentrate evaporation). ${ }^{*} \mathrm{P}-\mathrm{PO}_{4}$ content in the sediment after evaporation of the concentrate $\left(105^{\circ} \mathrm{C}\right)$.

osmotic equilibrium had been reached between i-PO4 concentration in the hydrogel and in the concentrate ${ }^{21}$. With each successive cycle, an increasing number of non-desorbed anions (i-PO4, $\mathrm{Cl}^{-}$) was left in the sorbent after desorption. Thus, the number of free sorption centers able to bind orthophosphates from the source solution decreased continuously in the successive cycles, leading to sorption efficiency decrease with each cycle (Fig. 5). No increase in i-PO4 concentration in the hydrogel in the last cycles caused no increase in their concentration in the concentrate (Fig. 6).

Concentrations of the concentrates obtained increased along with an increasing concentration of the source solution because the sorption efficiency increasing along with concentration increase. At the higher concentration of orthophosphate ions in the hydrogel, the osmotic equilibrium point allowed for a higher i-PO4 concentration 
in the concentrate. For the same reason, a higher concentration of the concentrate was obtained in the systems with CHs-ECH (Fig. 6).

The higher concentrations of i-PO4 determined in the concentrates in the first cycles at higher desorption $\mathrm{pH}$ ( $\mathrm{pH}$ 13) are due to a stronger negative charge of the sorbent, which enhanced desorption of orthophosphates. For the same reason, in the initial cycles of the experimental series with desorption performed at $\mathrm{pH} 13$, the efficiency of i-PO4 sorption from the source solutions was higher than in the series with desorption conducted at $\mathrm{pH}$ 12. Concentrate's $\mathrm{pH}$ was corrected (to $\mathrm{pH} 12 / \mathrm{pH} 13$ ) after each sorption/desorption cycle. Therefore, salinity and TDS content determined in the final cycles were significantly higher in the concentrates with $\mathrm{pH}$ 13 than in these with $\mathrm{pH} 12$, which could negatively affect orthophosphate desorption. Hence, in the last cycles, the maximum concentration of orthophosphates obtained in the concentrates with $\mathrm{pH} 12$ was ultimately higher than in these with $\mathrm{pH} 13$.

Supplement 3 presents analyses on the effect of sorbent type and source solution concentration on TDS contents in the concentrates and source solutions.

Supplement 4 presents analyses on the effect of sorbent type on the $\mathrm{pH}$ values of source solutions and concentrates in the successive sorption/desorption cycles.

Parameters of the orthophosphate concentrate in the last sorption/desorption cycle. In the last sorption/desorption cycle, the concentrate was analyzed for the concentration of chlorides. The concentrates obtained in the systems with $\mathrm{CHs}$ used as the ion carrier were characterized by multiply higher $\mathrm{Cl}^{-}$concentrations than these with CHs-ECH (Table 2). Chloride concentrations in the orthophosphate concentrates decreased along with an increase in the initial concentration of the source solutions. Besides, they were higher in the experimental series with desorption performed at the higher $\mathrm{pH}$ value ( $\mathrm{pH}$ 13) (Table 2).

The higher chloride concentrations in the series with CHs-ECH were due to the lower $\mathrm{pH}$ of the sorption process. Because $\mathrm{pH}$ value was corrected using $\mathrm{HCl}$, the source solutions from the systems with $\mathrm{CHs}-\mathrm{ECH}(\mathrm{pH}$ 3) had approximately tenfold higher chloride concentrations than these from the systems with $\mathrm{CHs}(\mathrm{pH} \mathrm{4})$. At the higher concentrations of chlorides, their sorption efficiency was higher, which resulted in their higher concentration in the concentrates.

The decreased concentration of $\mathrm{Cl}^{-}$in the concentrates along with an increasing initial concentration of i-PO4 in the source solutions was due to the lower chloride to orthophosphate ratio in the solution. At the higher concentrations of orthophosphates during the sorption process, the ratio of bound orthophosphates to bound chlorides increased, which caused a lower number of $\mathrm{Cl}^{-}$anions in the concentrate. The higher concentrations of chlorides in the experimental series with desorption conducted at $\mathrm{pH} 13$ are due to a stronger negative charge of the sorbent in the concentrate and more efficient desorption. Important was also the lesser affinity of chlorides to the amine groups of chitosan ${ }^{22}$, which additionally increased their desorption efficiency.

The mass of the recovered phosphorus, computed based on concentrate's concentration, increased along with an increasing concentration of the source solution (Table 2). The effect of desorption $\mathrm{pH}$ on phosphorus content in the concentrate was insignificant. The amounts of $\mathrm{P}_{-} \mathrm{PO}_{4}$ recovered in the systems with $\mathrm{CHs}$ - $\mathrm{ECH}$ were significantly higher compared to the systems with $\mathrm{CH}$. Phosphorus content determined in the concentrate in the experimental series with $\mathrm{CHs}-\mathrm{ECH}$ used as the ion carrier was even 30-fold higher than in the source solutions (at $\mathrm{C}_{\text {start }}=10 \mathrm{mg} \mathrm{P}-\mathrm{PO}_{4} / \mathrm{L}$ ).

The content of dry residue left after concentrate evaporation depended mainly on TDS content in the solution. It increased along with an increasing concentration of the source solution. The content of concentrate dry residue obtained in the last cycle was significantly higher in the experimental series with $\mathrm{CHs}-\mathrm{ECH}$ than in these with CHs (Table 2). Dry residue contents were also higher in the systems with higher desorption $\mathrm{pH}$ ( $\mathrm{pH} 13$ ).

The percentage contents of phosphorus $\left(\mathrm{P}-\mathrm{PO}_{4}\right)$ in the dry residue after concentrate evaporation increased along with an increasing initial concentration of the source solutions. They were strongly affected by desorption $\mathrm{pH}$. In the experimental series with the lower desorption $\mathrm{pH}(\mathrm{pH} 12)$, the purity of the recovered phosphorus was significantly higher than in these with the higher desorption $\mathrm{pH}(\mathrm{pH} 13)$.

The percentage contents of phosphorus $\left(\mathrm{P}-\mathrm{PO}_{4}\right)$ in the dry residue after concentrate evaporation were generally higher in the systems with $\mathrm{CHs}$ than with $\mathrm{CHs}-\mathrm{ECH}$ (Table 2). At desorption $\mathrm{pH} 12$, they ranged from 17.81 to $19.83 \%$ in the systems with $\mathrm{CHs}$ and from 16.04 to $17.74 \%$ in the systems with $\mathrm{CHs}-\mathrm{ECH}$.

The percentage contents of phosphorus $\left(\mathrm{P}_{-} \mathrm{PO}_{4}\right)$ in the dry residue after concentrate evaporation were mainly due to the ratio of i-PO4 to TDS contents in the concentrate. In turn, the effect of sorption and desorption parameters on i-PO4 and TDS contents in the concentrate was explained in the previous paragraphs of this section (and also in Supplement 3).

After physicochemical analyses, the solubility of the sediment after concentrate evaporation was determined by mixing it with a small volume of deionized water. In contact with water, the sediment dissolved completely, which points to the utile form of the recovered phosphorus.

\section{Summary}

The content of phosphorus in the dry residue left after concentrate evaporation reached max. $17.74 \%$ in the experimental series with CHs-ECH and even $19.83 \%$ in these with $\mathrm{CHs}$, suggesting that the recovered phosphorus was mainly in the form of sodium phosphates and hydrophosphates. The total solubility of the concentrate dry residue in a small volume of water points to the utile and convenient form of the recovered phosphorus.

The maximum concentration of orthophosphates in the concentrate ranged from 146.0 to $971.6 \mathrm{mg} \mathrm{P}^{-} \mathrm{PO}_{4} / \mathrm{L}$ and depended mainly on the initial $\mathrm{i}-\mathrm{PO}_{4}$ concentration in the source solutions and ion carrier type (sorbent type). Due to the better sorption efficiency of orthophosphates on $\mathrm{CHs}-\mathrm{ECH}$ than on $\mathrm{CHs}$, the experimental series with crosslinked chitosan were also characterized by higher concentrations of the concentrate obtained. 
The sorption of orthophosphates on the crosslinked chitosan sorbents was the most efficient at $\mathrm{pH}$ 3. Considering the dissolution of non-modified chitosan at $\mathrm{pH}<4$, the optimal $\mathrm{pH}$ of $\mathrm{i}-\mathrm{PO}_{4}$ sorption was $\mathrm{pH} 4$.

The sorption of orthophosphates on $\mathrm{CHs}-\mathrm{ECH}$ at low $\mathrm{pH}(\mathrm{pH} 3)$ resulted in very high TDS contents in the concentrates. Because the concentration of chlorides was approximately tenfold higher in the source solutions with $\mathrm{pH} 3\left(\mathrm{pH}\right.$ correction using $\mathrm{HCl}$ ) than in these with $\mathrm{pH} 4$, the $\mathrm{Cl}^{-}$sorption on $\mathrm{CHs}-\mathrm{ECH}$ was significantly higher than on $\mathrm{CHs}$. As a consequence, $\mathrm{CHs}-\mathrm{ECH}$ introduced greater amounts of chlorides to the concentrate than $\mathrm{CHs}$. Also, the higher concentration of chlorides in the concentrate required higher amounts of $\mathrm{NaOH}$ to correct concentrate's $\mathrm{pH}$ after each cycle. The higher $\mathrm{Cl}^{-}$and $\mathrm{Na}^{+}$concentrations in the concentrate increased its salinity and TDS content. Ultimately, the concentrates obtained in the experimental series with $\mathrm{CHs}-\mathrm{ECH}$ were more contaminated with $\mathrm{Cl}^{-}$and $\mathrm{Na}^{+}$ions.

The efficiency of orthophosphate desorption increased along with increasing $\mathrm{pH}$ of desorption solution. In the case of both $\mathrm{CHs}$ and $\mathrm{CHs}-\mathrm{ECH}$, desorption efficiency was the highest at $\mathrm{pH}$ 12-13. Even though the desorption process was more intense at high $\mathrm{pH}$ of desorption solutions, the final amounts of orthophosphates desorbed at $\mathrm{pH} 11, \mathrm{pH} 12$, and $\mathrm{pH} 13$ were similar, pointing to no need for the use of strongly alkaline solutions to perform effective desorption.

In the initial sorption/desorption cycles, the concentration of orthophosphates in the concentrate at $\mathrm{pH} 13$ was higher than in the series with the concentrate at $\mathrm{pH} 12$. Due to the rapid salination of the concentrate at pH 13 in the successive cycles, ultimately higher maximum concentrations of the concentrate were obtained in the experimental series with desorption performed at $\mathrm{pH}$ 12. The lower concentration of orthophosphates in the concentrates at $\mathrm{pH} 13$ and their higher salt content suggest that $\mathrm{P}-\mathrm{PO}_{4} / \mathrm{L}$ desorption should be conducted at relatively low $\mathrm{pH}$ values $(\mathrm{pH}<13)$.

The process of orthophosphate binding on chitosan sorbents was also largely influenced by the sorbent's contact time with the solution. In case of $\mathrm{CHs}$, it should range from 45 to $60 \mathrm{~min}$, whereas in the case of $\mathrm{CHs}-\mathrm{ECH}$ from 90 to $180 \mathrm{~min}$. Longer contact times could result in uncontrolled desorption of $\mathrm{i}-\mathrm{PO}_{4}$ to the source solution.

The optimal duration of $\mathrm{i}-\mathrm{PO}_{4}$ desorption from chitosan sorbents depended mainly on desorption $\mathrm{pH}$. It shortened along with desorption $\mathrm{pH}$ increase, due to a stronger negative charge of the sorbent at higher desorption $\mathrm{pH}$. Regardless of the concentration of source solutions, i- $\mathrm{PO}_{4}$ desorption from $\mathrm{CHs}$ should last from 60 to $120 \mathrm{~min}$ and that from CHs-ECH-from 90 to $120 \mathrm{~min}$. A too long contact time of the sorbent with the desorption solution could result in re-resorption of orthophosphates, that had earlier been released to the solution.

Received: 22 March 2021; Accepted: 10 August 2021

Published online: 18 August 2021

\section{References}

1. Van Vuuren, D. P., Bouwman, A. F. \& Beusen, A. H. W. Phosphorus demand for the 1970-2100 period: A scenario analysis of resource depletion. Glob. Environ. Chang. 20, 428-439 (2010).

2. Zhang, J. et al. Removal and recovery of phosphorus from low-strength wastewaters by flow-electrode capacitive deionization. Sep. Purif. Technol. 237, 66 (2020).

3. Gulyás, A., Genç, S., Can, Z. S. \& Semerci, N. Phosphate recovery from sewage sludge supernatants using magnetic nanoparticles. J. Water Process Eng. 40, 66 (2021).

4. Rahimpour Golroudbary, S., El Wali, M. \& Kraslawski, A. Rationality of using phosphorus primary and secondary sources in circular economy: Game-theory-based analysis. Environ. Sci. Policy 106, 166-176 (2020).

5. Zin, M. M. T., Tiwari, D. \& Kim, D. J. Recovery of ammonium and phosphate as struvite via integrated hydrolysis and incineration of sewage sludge. J. Water Process Eng. 39, 66 (2021).

6. Miyazato, T. et al. Phosphate recovery from an aqueous solution through adsorption-desorption cycle over thermally treated activated carbon. J. Water Process Eng. 36, 66 (2020).

7. Yasipourtehrani, S., Strezov, V. \& Evans, T. Investigation of phosphate removal capability of blast furnace slag in wastewater treatment. Sci. Rep. 9, 66 (2019).

8. Almasri, D. A., Saleh, N. B., Atieh, M. A., McKay, G. \& Ahzi, S. Adsorption of phosphate on iron oxide doped halloysite nanotubes. Sci. Rep. 9, 66 (2019).

9. Lei, Y., Saakes, M., van der Weijden, R. D. \& Buisman, C. J. N. Electrochemically mediated calcium phosphate precipitation from phosphonates: Implications on phosphorus recovery from non-orthophosphate. Water Res. 169, 66 (2020).

10. Sánchez, A. S. Technical and economic feasibility of phosphorus recovery from wastewater in São Paulo’s Metropolitan Region. J. Water Process Eng. 38, 66 (2020).

11. Vasenko, L. \& Qu, H. Enhancing the recovery of calcium phosphates from wastewater treatment systems through hybrid process of oxidation and crystallization. J. Environ. Chem. Eng. 7, 66 (2019).

12. Cunha, J. R. et al. Calcium phosphate granules recovered from black water treatment: A sustainable substitute for mined phosphorus in soil fertilization. Resour. Conserv. Recycl. 158, 66 (2020).

13. Nir, O., Sengpiel, R. \& Wessling, M. Closing the cycle: Phosphorus removal and recovery from diluted effluents using acid resistive membranes. Chem. Eng. J. 346, 640-648 (2018).

14. Ye, Z. L. et al. Adsorption behavior of tetracyclines by struvite particles in the process of phosphorus recovery from synthetic swine wastewater. Chem. Eng. J. 313, 1633-1638 (2017).

15. Li, B. et al. Phosphorus recovery through struvite crystallisation: Recent developments in the understanding of operational factors. J. Environ. Manag. 248, 66 (2019).

16. Soares, A. et al. Bio-Struvite: A new route to recover phosphorus from wastewater. Clean Soil Air Water 42, $994-997$ (2014).

17. Simoes, F., Vale, P., Stephenson, T. \& Soares, A. Understanding the growth of the bio-struvite production Brevibacterium antiquum in sludge liquors. Environ. Technol. 39, 2278-2287 (2018).

18. Chrispim, M. C., Scholz, M. \& Nolasco, M. A. Phosphorus recovery from municipal wastewater treatment: Critical review of challenges and opportunities for developing countries. J. Environ. Manag. 248, 66 (2019).

19. Diaz-Elsayed, N., Rezaei, N., Guo, T., Mohebbi, S. \& Zhang, Q. Wastewater-based resource recovery technologies across scale: A review. Resour. Conserv. Recycl. 145, 94-112 (2019).

20. Vasenko, L. \& Qu, H. Novel two-stage oxidation/crystallization technology for high-purity calcium phosphates recovery from digester supernatant. J. Environ. Chem. Eng. 6, 2975-2982 (2018). 
21. Bacelo, H., Pintor, A. M. A., Santos, S. C. R., Boaventura, R. A. R. \& Botelho, C. M. S. Performance and prospects of different adsorbents for phosphorus uptake and recovery from water. Chem. Eng. J. 381, 66 (2020).

22. Loganathan, P., Vigneswaran, S., Kandasamy, J. \& Bolan, N. S. Removal and recovery of phosphate from water using sorption. Crit. Rev. Environ. Sci. Technol. 44, 847-907 (2014).

23. Wan, J. et al. Zirconium-loaded magnetic interpenetrating network chitosan/poly(vinyl alcohol) hydrogels for phosphorus recovery from the aquatic environment. Appl. Surf. Sci. 423, 484-491 (2017).

24. Zhou, A. et al. Phosphorus recovery from water by lanthanum hydroxide embedded interpenetrating network poly (vinyl alcohol)/ sodium alginate hydrogel beads. Colloids Surf. A Physicochem. Eng. Asp. 554, 237-244 (2018).

25. You, X., Valderrama, C., Soldatov, V. \& Cortina, J. L. Phosphate recovery from treated municipal wastewater using hybrid anion exchangers containing hydrated ferric oxide nanoparticles. J. Chem. Technol. Biotechnol. 93, 358-364 (2018).

26. Antunes, E., Jacob, M. V., Brodie, G. \& Schneider, P. A. Isotherms, kinetics and mechanism analysis of phosphorus recovery from aqueous solution by calcium-rich biochar produced from biosolids via microwave pyrolysis. J. Environ. Chem. Eng. 6, 395-403 (2018).

27. Kuzawa, K. et al. Phosphate removal and recovery with a synthetic hydrotalcite as an adsorbent. Chemosphere 62, 45-52 (2006).

28. Fitzpatrick, J. et al. Pilot testing of a high efficiency adsorbent system for phosphorus removal and recovery to meet ultra-low phosphorus limits. Proc. Water Environ. Fed. 2009, 1025-1037 (2012).

29. El Bouraie, M. \& Masoud, A. A. Adsorption of phosphate ions from aqueous solution by modified bentonite with magnesium hydroxide $\mathrm{Mg}(\mathrm{OH})_{2}$. Appl. Clay Sci. 140, 157-164 (2017).

30. Hu, P. et al. Preparation of layered double hydroxides using boron mud and red mud industrial wastes and adsorption mechanism to phosphate. Water Environ. J. 31, 145-157 (2017).

31. Yan, H., Chen, Q., Liu, J., Feng, Y. \& Shih, K. Phosphorus recovery through adsorption by layered double hydroxide nanocomposites and transfer into a struvite-like fertilizer. Water Res. 145, 721-730 (2018).

32. Midorikawa, I. et al. Recovery of high purity phosphorus from municipal wastewater secondary effluent by a high-speed adsorbent. Water Sci. Technol. 58, 1601-1607 (2008).

33. Hamza, M. F. et al. Phosphorylation of guar gum/magnetite/chitosan nanocomposites for uranium(VI) sorption and antibacterial applications. Molecules 26, 1920 (2021).

34. Elwakeel, K. Z., Hamza, M. F. \& Guibal, E. Effect of agitation mode (mechanical, ultrasound and microwave) on uranium sorption using amine- and dithizone-functionalized magnetic chitosan hybrid materials. Chem. Eng. J. 411, 128553 (2021).

35. Elwakeel, K. Z., Al-Bogami, A. S. \& Guibal, E. 2-Mercaptobenzimidazole derivative of chitosan for silver sorption-Contribution of magnetite incorporation and sonication effects on enhanced metal recovery. Chem. Eng. J. 403, 126265 (2021).

36. Almughamisi, M. S., Khan, Z. A., Alshitari, W. \& Elwakeel, K. Z. Recovery of chromium(VI) oxyanions from aqueous solution using $\mathrm{Cu}(\mathrm{OH})_{2}$ and $\mathrm{CuO}$ embedded chitosan adsorbents. J. Polym. Environ. 28, 47-60 (2020).

37. Elwakeel, K. Z., Aly, M. H., El-Howety, M. A., El-Fadaly, E. \& Al-Said, A. Synthesis of Chitosan@activated carbon beads with abundant amino groups for capture of $\mathrm{Cu}$ (II) and $\mathrm{Cd}(\mathrm{II})$ from aqueous solutions. J. Polym. Environ. 26, 3590-3602 (2018).

38. ELwakeel, K. Z., El-Kousy, S., El-Shorbagy, H. G. \& El-Ghaffar, M. A. A. ,. Comparison between the removal of Reactive Black 5 from aqueous solutions by 3 -amino-1,2,4 triazole,5-thiol and melamine grafted chitosan prepared through four different routes. J. Environ. Chem. Eng. 4, 733-745 (2016).

39. Jóźwiak, T., Filipkowska, U., Szymczyk, P., Kuczajowska-Zadrożna, M. \& Mielcarek, A. The use of cross-linked chitosan beads for nutrients (nitrate and orthophosphate) removal from a mixture of $\mathrm{P}^{-} \mathrm{PO}_{4}, \mathrm{~N}-\mathrm{NO}_{2}$ and $\mathrm{N}-\mathrm{NO}_{3}$. Int. J. Biol. Macromol. 104, 1280-1293 (2017).

40. Jóźwiak, T., Filipkowska, U., Szymczyk, P., Rodziewicz, J. \& Mielcarek, A. Effect of ionic and covalent crosslinking agents on properties of chitosan beads and sorption effectiveness of Reactive Black 5 dye. React. Funct. Polym. 114, 58-74 (2017).

41. Zhao, T. \& Feng, T. Application of modified chitosan microspheres for nitrate and phosphate adsorption from aqueous solution. RSC Adv. 6, 90878-90886 (2016).

42. Zhao, Y. et al. Function integrated chitosan-based beads with throughout sorption sites and inherent diffusion network for efficient phosphate removal. Carbohydr. Polym. 230, 66 (2020).

43. Huang, Y. et al. A sustainable adsorbent for phosphate removal: modifying multi-walled carbon nanotubes with chitosan. J. Mater. Sci. 53, 12641-12649 (2018).

\section{Acknowledgements}

This study was financed under Project No. 18.610.008-300 of the University of Warmia and Mazury in Olsztyn, Poland. Project financially supported by Minister of Science and Higher Education in the range of the program entitled "Regional Initiative of Excellence" for the years 2019-2022, Project No. 010/RID/2018/19, amount of funding 12.000.000 PLN.

\section{Author contributions}

T.J.-Conceptualization; Supervision; Writing_Original Draft; A.K.—Writing-Review \& Editing; Formal analysis; U.F.-Writing-Review \& Editing; Formal analysis; Resources J.S.-S.-Writing-Review \& Editing; Formal analysis; L.B.-Investigation; Data Curation; L.G.-Investigation; Data Curation; M.I.-Investigation; Data Curation.

\section{Competing interests}

The authors declare no competing interests.

\section{Additional information}

Supplementary Information The online version contains supplementary material available at https://doi.org/ 10.1038/s41598-021-96416-2.

Correspondence and requests for materials should be addressed to T.J.

Reprints and permissions information is available at www.nature.com/reprints.

Publisher's note Springer Nature remains neutral with regard to jurisdictional claims in published maps and institutional affiliations. 
(c) (i) Open Access This article is licensed under a Creative Commons Attribution 4.0 International cc) License, which permits use, sharing, adaptation, distribution and reproduction in any medium or format, as long as you give appropriate credit to the original author(s) and the source, provide a link to the Creative Commons licence, and indicate if changes were made. The images or other third party material in this article are included in the article's Creative Commons licence, unless indicated otherwise in a credit line to the material. If material is not included in the article's Creative Commons licence and your intended use is not permitted by statutory regulation or exceeds the permitted use, you will need to obtain permission directly from the copyright holder. To view a copy of this licence, visit http://creativecommons.org/licenses/by/4.0/.

(C) The Author(s) 2021 